\title{
Orientation relationships, interface structures, and mechanical properties of directionally solidified $\mathrm{MoSi}_{2} / \mathrm{Mo}_{5} \mathrm{Si}_{3} / \mathrm{Mo}_{5} \mathrm{Si}_{3} \mathrm{C}$ composites
}

\author{
Hirotaka Matsunoshita $^{1, *}$, Kosuke Fujiwara $^{1}$, Yuta Sasai ${ }^{1}$, Kyosuke Kishida ${ }^{1,2}$ and \\ Haruyuki Inui ${ }^{1,2}$ \\ ${ }^{1}$ Department of Materials Science and Engineering, Kyoto University, \\ Sakyo-ku, Kyoto 606-8501, Japan \\ ${ }^{2}$ Center for Elements Strategy Initiative for Structural Materials (ESISM), Kyoto \\ University, \\ Sakyo-ku, Kyoto 606-8501, Japan \\ * Corresponding author: Hirotaka Matsunoshita \\ Department of Materials Science and Engineering, Kyoto University, \\ Sakyo-ku, Kyoto 606-8501, Japan \\ E-mail address: matsunoshita.hirotaka.53z@ st.kyoto-u.ac.jp \\ Tel.: +81-75-753-5473, fax: +81-75-753-5461
}

\begin{abstract}
The microstructures, orientation relationships, and high-temperature deformation behavior of directionally solidified (DS) ingots of $\mathrm{MoSi}_{2} / \mathrm{Mo}_{5} \mathrm{Si}_{3} / \mathrm{Mo}_{5} \mathrm{Si}_{3} \mathrm{C}$ three-phase eutectic composites were investigated. DS three-phase composites exhibit a fine and homogeneous script lamellar microstructure. $\mathrm{Mo}_{5} \mathrm{Si}_{3}$ and $\mathrm{Mo}_{5} \mathrm{Si}_{3} \mathrm{C}$ individually form interconnected networks that extend in the growth direction (GD) of the $\mathrm{MoSi}_{2}$ matrix and maintain $[1 \overline{1} 0]_{\mathrm{MoSi}_{2}},[001]_{\mathrm{Mo}_{5} \mathrm{Si}_{3}}$, and $[0001]_{\mathrm{Mo}_{5} \mathrm{Si}_{3} \mathrm{C}}$ approximately parallel to the GD. High-temperature strength is higher in the DS three-phase composite than in the
\end{abstract}


binary two-phase counterpart, especially below $1200{ }^{\circ} \mathrm{C}$. This is mainly because of $\mathrm{MoSi}_{2}$ matrix refinement and the presence of the strengthening phase $\mathrm{Mo}_{5} \mathrm{Si}_{3} \mathrm{C}$. The observed orientation relationship between component phases is discussed in relation to lattice misfits.

Key words: A. transition-metal silicides; B. alloy design; B. mechanical properties; D. microstructure; D. interfaces

\section{Introduction}

One of the greatest challenges for improving efficiency in advanced combustion systems such as gas turbine power plants and aircraft engines is developing ultra-high temperature materials that drastically increase combustion temperatures beyond the maximum operating temperatures of current $\mathrm{Ni}$-based superalloys. $\mathrm{MoSi}_{2}$ with the tetragonal $\mathrm{C} 11_{\mathrm{b}}$ structure has received considerable attention because of its attractive properties such as a high melting point $\left(2020{ }^{\circ} \mathrm{C}\right)$, excellent oxidation resistance, and relatively low density [1-5]. However, poor fracture toughness at room temperature and insufficient strength at elevated temperatures should be improved for its practical application as ultra-high temperature structural materials. Extensive efforts to improve the insufficient mechanical properties of monolithic $\mathrm{MoSi}_{2}$ have been made by forming composites with hard ceramics or intermetallics such as $\mathrm{SiC}, \mathrm{TiC}, \mathrm{ZrO}_{2}$, and $\mathrm{Mo}_{5} \mathrm{Si}_{3}[5,6]$. Among these composites, $\mathrm{MoSi}_{2} / \mathrm{Mo}_{5} \mathrm{Si}_{3}$ eutectic composites with high eutectic temperatures of approximately $1900{ }^{\circ} \mathrm{C}$ are expected to have higher probability for the property improvements of $\mathrm{MoSi}_{2}$ through interface property control due to the fine script lamellar microstructure that forms via directional solidification (DS) [7-11]. 


\section{Experimental}

Rod ingots of the ternary alloy with a nominal composition of Mo - 52 at.\% Si - 2 at.\% $\mathrm{C}$ were prepared by arc melting. DS ingots were grown from the rod ingots by the optical floating-zone method at a growth rate of $10 \mathrm{~mm} / \mathrm{h}$ under Ar gas flow. Microstructures of the DS ingots were examined by scanning electron microscopy (SEM), electron backscatter diffraction (EBSD) in SEM, transmission electron microscopy (TEM), and scanning transmission electron microscopy (STEM). The SEM 
examinations were carried out in a JEOL JSM-7001FA electron microscope with a field emission gun (FEG) operated at 15 or $20 \mathrm{kV}$ and a TSL DVC5-type EBSD detector. Thin foils for TEM/STEM observations were cut from the DS ingots, polished mechanically and then Ar ion milled using a JEOL EM-09100IS ion milling machine operated at $6.0 \mathrm{kV}$ for milling and $2.0 \mathrm{kV}$ for finishing. The TEM/STEM analysis was carried out in a JEOL JEM-ARM200F equipped with a cold FEG operated at $200 \mathrm{kV}$. Lattice parameters of the component phases were determined by powder X-ray diffraction (XRD) with a Rigaku Miniflex II diffractometer operated at $30 \mathrm{kV}, 15 \mathrm{~mA}$.

Oriented single crystalline specimens $1.4 \times 1.4 \times 3.5 \mathrm{~mm}^{3}$ in size were cut from the DS ingots by electro discharge machining (EDM) for compression tests, which were performed along $[1 \overline{1} 0]_{\mathrm{MoSi}_{2}}$ nearly parallel to the growth direction (GD) of the DS ingots in the temperature range of 900 to $1400{ }^{\circ} \mathrm{C}$ in a vacuum at a nominal strain rate of $10^{-4} \mathrm{~s}^{-1}$.

\section{Results}

\subsection{Microstructures and orientation relationships}

DS ingots of $\mathrm{MoSi}_{2} / \mathrm{Mo}_{5} \mathrm{Si}_{3} / \mathrm{Mo}_{5} \mathrm{Si}_{3} \mathrm{C}$ three-phase eutectic composites exhibit a fine script lamellar microstructure similar to DS $\mathrm{MoSi}_{2} / \mathrm{Mo}_{5} \mathrm{Si}_{3}$ eutectic composites [7,12]. Fig. 1 shows EBSD orientation maps analyzed on one cross-section and two longitudinal sections of the DS three-phase composite. Orientation distributions of the three component phases along the GD of the DS ingot are indicated in Fig. 1. The three regions, namely, blue, green, and red correspond to $\mathrm{MoSi}_{2}, \mathrm{Mo}_{5} \mathrm{Si}_{3}$, and $\mathrm{Mo}_{5} \mathrm{Si}_{3} \mathrm{C}$, respectively. $\mathrm{Mo}_{5} \mathrm{Si}_{3}$ and $\mathrm{Mo}_{5} \mathrm{Si}_{3} \mathrm{C}$ phases clearly form individual interconnected 
networks extending along the GD in the $\mathrm{MoSi}_{2}$ matrix and maintain $[1 \overline{1} 0]_{\mathrm{MoSi}_{2}}$, $[001]_{\mathrm{Mo}_{5} \mathrm{Si}_{3}}$, and $[0001]_{\mathrm{Mo}_{5} \mathrm{Si}_{3} \mathrm{C}}$ approximately parallel to the GD (Fig. 1(b)). Approximate orientation relationships among three phases determined by the EBSD analysis are summarized as follows (EBSD orientation maps are shown in supplementary material):

$$
\begin{aligned}
& {[1 \overline{1} 0]_{\mathrm{MoSi}_{2}} / /[001]_{\mathrm{Mo}_{5} \mathrm{Si}_{3}} / /[0001]_{\mathrm{Mo}_{5} \mathrm{Si}_{3} \mathrm{C}}} \\
& {[110]_{\mathrm{MoSi}_{2}} / /[1 \overline{1} 0]_{\mathrm{Mo}_{5} \mathrm{Si}_{3}} / /[2 \overline{3} 10]_{\mathrm{Mo}_{0_{3} \mathrm{Si}_{3} \mathrm{C}}}} \\
& {[001]_{\mathrm{MoSi}_{2}} / /[110]_{\mathrm{Mo}_{5} \mathrm{Si}_{3}} / /[41 \overline{5} 0]_{\mathrm{Mos}_{5} \mathrm{Si}_{3} \mathrm{C}}}
\end{aligned}
$$

The orientation relationship between $\mathrm{MoSi}_{2}$ and $\mathrm{Mo}_{5} \mathrm{Si}_{3}$ is identical with that observed in DS $\mathrm{MoSi}_{2} / \mathrm{Mo}_{5} \mathrm{Si}_{3}$ two-phase eutectic composites, described as (110) ${ }_{\mathrm{MoSi}_{2}} / /$ $(1 \overline{1} 0)_{\mathrm{MoS}_{5} \mathrm{Si}_{3}}$ and $[1 \overline{1} 0]_{\mathrm{MoSi}_{2}} / /[001]_{\mathrm{Mos}_{5} \mathrm{Si}_{3}}$ with a minor misalignment of $\sim 2^{\circ}$ between $[1 \overline{1} 0]_{\mathrm{MoSi}_{2}}$ and $[001]_{\mathrm{Mo}_{5} \mathrm{~S}_{3}}$ [7,9]. A slight misalignment of $\sim 1^{\circ}$ is also confirmed between $[2 \overline{3} 10]_{\mathrm{Mos}_{5} \mathrm{Si}_{3} \mathrm{C}}$ and $[110]_{\mathrm{MoSi}_{2}} / /[1 \overline{1} 0]_{\mathrm{Mo}_{5} \mathrm{Si}_{3}}$ by diffraction analysis in TEM as shown in Fig 3. Approximate crystallographic orientations of the three component phases in each section are indicated in Fig. 1. The volume fraction of $\mathrm{MoSi}_{2}, \mathrm{Mo}_{5} \mathrm{Si}_{3}$, and $\mathrm{Mo}_{5} \mathrm{Si}_{3} \mathrm{C}$ in the three-phase composite is estimated to have a ratio of $48.3 \pm 1.1: 26.2 \pm 0.8: 25.5 \pm$ 0.7 based on the phase area fraction data obtained from seven rectangular areas of about $150 \mu \mathrm{m} \times 450 \mu \mathrm{m}$ analyzed by SEM-EBSD. Because $\mathrm{Mo}_{5} \mathrm{Si}_{3}$ and $\mathrm{Mo}_{5} \mathrm{Si}_{3} \mathrm{C}$ have rod-like morphology, no correction is required to estimate the volume fraction from the phase area fraction data.

A typical SEM backscattered electron image observed from a cross-section of the DS three-phase eutectic composite as well as that of the two-phase counterpart is 
shown in Fig. 2. The three component phases of $\mathrm{MoSi}_{2}, \mathrm{Mo}_{5} \mathrm{Si}_{3}$, and $\mathrm{Mo}_{5} \mathrm{Si}_{3} \mathrm{C}$ appear as dark, light, and medium gray regions, respectively. The $\mathrm{Mo}_{5} \mathrm{Si}_{3}$ branches in the three-phase composite exhibit rectangular shapes similar to those observed in the two-phase counterpart (Fig. 2). Each $\mathrm{Mo}_{5} \mathrm{Si}_{3} \mathrm{C}$ rod form a connection between the neighboring $\mathrm{Mo}_{5} \mathrm{Si}_{3}$ branches (Fig. 2(a)) and divide the $\mathrm{MoSi}_{2}$ matrix into smaller regions compared to that in the two-phase composite (Fig. 2(b)). Consequently, the average thickness of the $\mathrm{MoSi}_{2}$ matrix along two orthogonal directions of $[001]_{\mathrm{MoSi}_{2}}$ and $[110]_{\mathrm{MoSi}_{2}}$ is reduced to $4.2 \pm 2.0$ and $5.6 \pm 4.2 \mu \mathrm{m}$, respectively, compared with $7.1 \pm 8.1$ and $6.1 \pm 4.6 \mu \mathrm{m}$ for the binary two-phase counterpart produced at the same growth rate of $10 \mathrm{~mm} / \mathrm{h}$. The average thicknesses of the $\mathrm{MoSi}_{2}$ matrix along $[001]_{\mathrm{MoSi}_{2}}$ and $[110]_{\mathrm{MoSi}_{2}}$ are obtained from $\sim 100$ thickness measurements for each direction using test grids drawn on SEM images of the $(1 \overline{1} 0)_{\mathrm{MoSi}_{2}}$ cross-section.

Orientation relationships and interface structures between $\mathrm{Mo}_{5} \mathrm{Si}_{3} \mathrm{C}$ and the other two phases were further investigated by TEM and atomic-resolution high-angle annular dark-field (HAADF)-STEM. Fig. 3 shows selected-area electron diffraction (SAED) patterns taken from the $\mathrm{Mo}_{5} \mathrm{Si}_{3} / \mathrm{Mo}_{5} \mathrm{Si}_{3} \mathrm{C}$ and $\mathrm{MoSi}_{2} / \mathrm{Mo}_{5} \mathrm{Si}_{3} \mathrm{C}$ interface regions with the incident beam direction parallel to $[0001]_{\mathrm{Mo}_{5} \mathrm{Si}_{3} \mathrm{C}}$. As indicated in the SAED pattern taken from the $\mathrm{Mo}_{5} \mathrm{Si}_{3} / \mathrm{Mo}_{5} \mathrm{Si}_{3} \mathrm{C}$ interface region (Fig. 3(a)), the diffraction spots of $550_{\mathrm{Mo}_{5} \mathrm{Si}_{3}}$ and $41 \overline{5} 0_{\mathrm{Mo}_{5} \mathrm{Si}_{3} \mathrm{C}}$ are very closely located with a minor deviation of $\sim 1^{\circ}$ around the incident beam direction. Moreover, $\overline{3} 30_{\mathrm{MoS}_{5} \mathrm{Si}_{3}}$ and $\overline{2} 3 \overline{1} \mathrm{O}_{\mathrm{Mo}_{5} \mathrm{Si}_{3} \mathrm{C}}$ have a similar relationship, consistent with the orientation relationship obtained by EBSD analysis. In addition, diffraction spots of $4 \overline{2} 0_{\mathrm{Mo}_{5} \mathrm{Si}_{3}}$ and $3 \overline{3} 00_{\mathrm{Mo}_{5} \mathrm{Si}_{3} \mathrm{C}}$ appear at nearly 
the same position with $\sim 0.5^{\circ}$ deviation around the incident beam direction (Figs. 3(a) and (b)). Thus, the orientation relationship between $\mathrm{Mo}_{5} \mathrm{Si}_{3}$ and $\mathrm{Mo}_{5} \mathrm{Si}_{3} \mathrm{C}$ is slightly better described as

$$
(2 \overline{1} 0)_{\mathrm{Mo}_{5} \mathrm{Si}_{3}} / /(1 \overline{1} 00)_{\mathrm{Mo}_{5} \mathrm{Si}_{3} \mathrm{C}},[001]_{\mathrm{Mo}_{5} \mathrm{Si}_{3}} / /[0001]_{\mathrm{Mo}_{5} \mathrm{Si}_{3} \mathrm{C}}
$$

The orientation relationship between $\mathrm{MoSi}_{2}$ and $\mathrm{Mo}_{5} \mathrm{Si}_{3} \mathrm{C}$ described by Eq. (1) is also confirmed by diffraction analysis in TEM as summarized in Figs. 3(c) and (d).

An atomic-resolution HAADF-STEM image of a typical $\mathrm{Mo}_{5} \mathrm{Si}_{3} / \mathrm{Mo}_{5} \mathrm{Si}_{3} \mathrm{C}$ interface with a habit plane macroscopically parallel to $(2 \overline{1} 0)_{\mathrm{Mo}_{5} \mathrm{Si}_{3}}-(1 \overline{1} 00)_{\mathrm{Mos}_{5} \mathrm{Si}_{3} \mathrm{C}}$ is shown in Fig. 4(a). The interface exhibits relatively high coherence (Fig. 4(a)). This is demonstrated by the connection of each black line that corresponds to traces of the $(110)_{\mathrm{Mo}_{5} \mathrm{Si}_{3}}$ planes to a black line of a $(10 \overline{1} 0)_{\mathrm{Mo}_{5} \mathrm{Si}_{3} \mathrm{C}}$ trace at the interface. Schematic illustration of the $(2 \overline{1} 0)_{\mathrm{Mo}_{5} \mathrm{Si}_{3}}-(1 \overline{1} 00)_{\mathrm{Mo}_{5} \mathrm{Si}_{3} \mathrm{C}}$ interface clearly indicates that atomic columns corresponding to Mo-chain sites in both of the phases ( $4 b$ and $4 d$ sites for $\mathrm{Mo}_{5} \mathrm{Si}_{3}$ and $\mathrm{Mo}_{5} \mathrm{Si}_{3} \mathrm{C}$, respectively) are periodically shared at the interface (Fig. 4 (c)). This type of interface structure with very high coherence is apparently not observed at any of the $\mathrm{MoSi}_{2} / \mathrm{Mo}_{5} \mathrm{Si}_{3} \mathrm{C}$ interfaces (Fig. 4(b)). Thus, orientation relationships of the $\mathrm{Mo}_{5} \mathrm{Si}_{3} \mathrm{C}$ phase with respect to $\mathrm{MoSi}_{2}$ and $\mathrm{Mo}_{5} \mathrm{Si}_{3}$ are considered to be selected primarily to form the $(2 \overline{1} 0)_{\mathrm{Mo}_{5} \mathrm{Si}_{3}}-(1 \overline{1} 00)_{\mathrm{Mo}_{5} \mathrm{Si}_{3} \mathrm{C}}$ interface with relatively high coherence.

\subsection{High-temperature deformation behavior}

Fig. 5(a) illustrates typical stress-strain curves obtained for $[1 \overline{1} 0]_{\mathrm{MoSi}_{2}}$ -oriented specimens of the DS three- and two-phase composites compressed by $2 \sim 4 \%$ 
plastic strain. Plastic flow is confirmed above $1000{ }^{\circ} \mathrm{C}$ for both the DS three- and two-phase composites. The stress-strain curves exhibit yield drop behavior. Similar yield drop behavior has been frequently observed in compression tests of single crystals of many transition-metal silicides including the [001]-oriented $\mathrm{Mo}_{5} \mathrm{Si}_{3}$ and [0001]-oriented $\mathrm{Mo}_{5} \mathrm{Si}_{3} \mathrm{C}$ [1,14-19]. This implies how difficult it is to activate dislocation sources or introduce new dislocations in these materials. The temperature dependence of the yield stress that corresponds to the flow stress at $0.2 \%$ plastic strain is plotted in Fig. 5(b). The temperature dependence curves of the yield stress for $\mathrm{MoSi}_{2}$, $\mathrm{Mo}_{5} \mathrm{Si}_{3}$, and $\mathrm{Mo}_{5} \mathrm{Si}_{3} \mathrm{C}$ single crystals tested along the corresponding loading axis orientations of $<110>_{\mathrm{MoSi}_{2}},[001]_{\mathrm{Mo}_{5} \mathrm{Si}_{3}}$, and $[0001]_{\mathrm{Mo}_{5} \mathrm{Si}_{3} \mathrm{C}}$ are also provided in Fig. 5(b) for reference $[1,14,15]$. The yield stress for the three-phase composites decreases monotonously with increasing temperature in the temperature range of 1000 to $1400{ }^{\circ} \mathrm{C}$. The yield stress at $1000{ }^{\circ} \mathrm{C}$ for the three-phase composites is much higher $(\sim 64 \%)$ than that for the binary counterparts, while above $1200{ }^{\circ} \mathrm{C}$ they are nearly identical. This indicates that the $\mathrm{Mo}_{5} \mathrm{Si}_{3} \mathrm{C}$ addition effectively improves yield strength, especially below $1200{ }^{\circ} \mathrm{C}$.

Fig. 6 shows deformation markings observed on two orthogonal side surfaces, namely, $(\overline{1} \overline{1} 0)_{\mathrm{MoSi}_{2}}$ and $(001)_{\mathrm{MoSi}_{2}}$, of the DS three-phase composites compressed to $\sim 2 \%$ plastic strain at $1000{ }^{\circ} \mathrm{C}$. Slip traces are observed in the $\mathrm{MoSi}_{2}$ matrix on the $(\overline{1} \overline{1} 0)_{\mathrm{MoSi}_{2}}$ surface but not on the $(001)_{\mathrm{MoSi}_{2}}$ surface. This suggests that the slip directions of the $\mathrm{MoSi}_{2}$ matrix are parallel to $(001)_{\mathrm{MoSi}_{2}}$. The $\{011\}<100>,\{010\}<100>$, $\{023\}<100>$, and $\{013\}<331>$ slip systems were reported to operate in compression tests of [110]-oriented $\mathrm{MoSi}_{2}$ single crystals [1]. Among these possible slip systems, the 


\section{Discussion}

\subsection{Orientation relationship among three component phases}

Among various interfaces in the DS $\mathrm{MoSi}_{2} / \mathrm{Mo}_{5} \mathrm{Si}_{3} / \mathrm{Mo}_{5} \mathrm{Si}_{3} \mathrm{C}$ three-phase composite, one type of $\mathrm{Mo}_{5} \mathrm{Si}_{3} / \mathrm{Mo}_{5} \mathrm{Si}_{3} \mathrm{C}$ interface being macroscopically parallel to $(2 \overline{1} 0)_{\mathrm{Mo}_{5} \mathrm{Si}_{3}}$ and $(1 \overline{1} 00)_{\mathrm{Mo}_{5} \mathrm{Si}_{3} \mathrm{C}}$ exhibits relatively high coherence. In general, the orientation relationship between two phases, stable interface structure, and interface properties are all closely related to the lattice misfits between component phases $[7,20]$. Thus, it is important to consider the relationship between the observed orientation relationship and lattice misfits to understand why the observed orientation relationships are preferentially selected. The $\mathrm{Mo}_{5} \mathrm{Si}_{3} / \mathrm{Mo}_{5} \mathrm{Si}_{3} \mathrm{C}$ interfaces form to connect intersections between the $\{110\}_{\mathrm{Mo}_{5} \mathrm{Si}_{3}}$ and $\{1 \overline{1} 00\}_{\mathrm{Mo}_{5} \mathrm{Si}_{3} \mathrm{C}}$ traces when the interfaces are viewed along the common direction parallel to $[001]_{\mathrm{Mo}_{5} \mathrm{Si}_{3}}$ and $[0001]_{\mathrm{Mo}_{5} \mathrm{Si}_{3} \mathrm{C}}$. Thus, it is reasonable to consider the lattice misfit between $\{110\}_{\mathrm{Mo}_{5} \mathrm{Si}_{3}}$ and $\{1 \overline{1} 00\}_{\mathrm{Mo}_{5} \mathrm{Si}_{3} \mathrm{C}}$ (misfit A) defined by 
the equation

$$
\text { Misfit } \mathrm{A}=2 \frac{d_{\{110\} \text { of } \mathrm{Mo}_{5} \mathrm{Si}_{3}}-d_{\{1 \overline{1} 00\} \text { of } \mathrm{Mo}_{5} \mathrm{Si}_{3} \mathrm{C}}}{d_{\{110\} \text { of } \mathrm{Mo}_{5} \mathrm{Si}_{3}}+d_{\{1 \overline{1} 00\} \text { of } \mathrm{Mo}_{5} \mathrm{Si}_{3} \mathrm{C}}}
$$

where $d_{\{h k l\} \text { of } \mathrm{Mo}_{5} \mathrm{Si}_{3}}$ and $d_{\{h k i l\} \text { of } \mathrm{Mo}_{5} \mathrm{Si}_{3} \mathrm{C}}$ correspond to the interplanar distances of $\{h k l\}$ in $\mathrm{Mo}_{5} \mathrm{Si}_{3}$ and $\{h k i l\}$ in $\mathrm{Mo}_{5} \mathrm{Si}_{3} \mathrm{C}$, respectively. An additional lattice misfit exists between $(001)_{\mathrm{Mo}_{5} \mathrm{Si}_{3}}$ and $(0001)_{\mathrm{Mo}_{5} \mathrm{Si}_{3} \mathrm{C}}$ (misfit B) and is estimated as

$$
\text { Misfit B }=2 \frac{d_{(001) \text { of } \mathrm{Mo}_{5} \mathrm{Si}_{3}}-d_{(0001) \text { of } \mathrm{Mo}_{5} \mathrm{Si}_{3} \mathrm{C}}}{d_{(001) \text { of } \mathrm{Mo}_{5} \mathrm{Si}_{3}}+d_{(0001) \text { of } \mathrm{Mo}_{5} \mathrm{Si}_{3} \mathrm{C}}}
$$

The values of misfits A and B are calculated as $8.0 \%$ and $-3.2 \%$, respectively using the lattice parameters $a_{\mathrm{Mo}_{5} \mathrm{Si}_{3}}=0.966 \mathrm{~nm}, c_{\mathrm{Mo}_{5} \mathrm{Si}_{3}}=0.489 \mathrm{~nm}, a_{\mathrm{Mo}_{5} \mathrm{Si}_{3} \mathrm{C}}=0.728 \mathrm{~nm}$, and $c_{\mathrm{Mo}_{5} \mathrm{Si}_{3} \mathrm{C}}=0.505 \mathrm{~nm}$ determined from powder XRD data of the ternary composites. Lattice misfit A with a larger absolute value has a strong influence on the observed orientation relationship. A relatively large misfit such as misfit A can be macroscopically accommodated by tilting one of the two crystals with respect to the other across the interface as in the $\mathrm{MoSi}_{2}$ and $\mathrm{Mo}_{5} \mathrm{Si}_{3}$ interface examined in our previous study [7,20]. Fig. 7 schematically illustrates the misfit accommodation. If a tilt with angle $\varphi$ between $(110)_{\mathrm{Mo}_{5} \mathrm{Si}_{3}}$ and $(10 \overline{1} 0)_{\mathrm{Mo}_{5} \mathrm{Si}_{3} \mathrm{C}}$ is introduced keeping $[001]_{\mathrm{Mo}_{5} \mathrm{Si}_{3}}$ and $[0001]_{\mathrm{Mo}_{5} \mathrm{Si}_{3} \mathrm{C}}$ parallel to each other, the lattice misfit $\mathrm{A}_{1}$ between $(110)_{\mathrm{Mo}_{5} \mathrm{Si}_{3}}$ and $(10 \overline{1} 0)_{\mathrm{Mo}_{5} \mathrm{Si}_{3} \mathrm{C}}$ is completely accommodated on the interfaces labeled $\mathrm{OP}_{1}$ and $\mathrm{OP}_{1}$ ' with interface inclination angles $\theta_{1}$ and $\theta_{1}$, , respectively. Because $\mathrm{Mo}_{5} \mathrm{Si}_{3} \mathrm{C}$ has a hexagonal lattice, two additional sets of $\{1 \overline{1} 00\}_{\mathrm{Mo}_{5} \mathrm{Si}_{3} \mathrm{C}}$, namely, $(0 \overline{1} 10)_{\mathrm{Mo}_{5} \mathrm{Si}_{3} \mathrm{C}}$ and $(1 \overline{1} 00)_{\mathrm{Mos}_{5} \mathrm{Si}_{3} \mathrm{C}}$, and one more set of $\{110\}_{\mathrm{Mo}_{5} \mathrm{Si}_{3}}$; i.e., $(1 \overline{1} 0)_{\mathrm{Mo}_{5} \mathrm{Si}_{3}}$, for the tetragonal $\mathrm{Mo}_{5} \mathrm{Si}_{3}$ can be simultaneously considered as illustrated in Fig. 7. The relationship between the tilt angle 
$\varphi$ and the interface inclination angle $\theta\left(\theta_{i}\right.$ and $\left.\theta_{i}{ }^{\prime}\right)$ for the three sets of $\{1 \overline{1} 00\}_{\mathrm{MoS}_{5} \mathrm{Si}_{3} \mathrm{C}}$, namely, $(10 \overline{1} 0)_{\mathrm{Mo}_{5} \mathrm{Si}_{3} \mathrm{C}}(i=1),(1 \overline{1} 00)_{\mathrm{Mo}_{5} \mathrm{Si}_{3} \mathrm{C}}(i=2)$, and $(0 \overline{1} 10)_{\mathrm{Mo}_{5} \mathrm{Si}_{3} \mathrm{C}}(i=3)$, with respect to $(110)_{\mathrm{Mo}_{5} \mathrm{Si}_{3}}$ defined in Fig. 7 are described by the following equations:

$$
\begin{array}{ll}
\tan \theta_{i}=\frac{d_{1} \cdot \sin \varphi_{i}}{d_{1} \cdot \cos \varphi_{i}-d_{2}} & (i=1,2, \text { and } 3) \\
\tan \theta_{i}{ }^{\prime}=\frac{d_{1} \cdot \sin \varphi_{i}}{d_{1} \cdot \cos \varphi_{i}+d_{2}} & (i=1,2 \text { and } 3)
\end{array}
$$

where $d_{1}=k \cdot d_{\{110\} \text { of } \mathrm{Mo}_{5} \mathrm{Si}_{3}}, d_{2}=l \cdot d_{\{1 \overline{1} 00\} \text { of } \mathrm{Mo}_{5} \mathrm{Si}_{3} \mathrm{C}}(k, l$ : positive integers $)$, and $\varphi_{i}=\varphi(i$ $=1), \varphi+60^{\circ}(i=2)$, and $\varphi+120^{\circ}(i=3)$. When both $k$ and $l$ are equal to 1 , a one-to-one connection between the $\{1 \overline{1} 00\}_{\mathrm{Mo}_{5} \mathrm{Si}_{3} \mathrm{C}}$ plane and the $(110)_{\mathrm{Mo}_{5} \mathrm{Si}_{3}}$ plane is achieved. When the number $k$ is equal to 1 and the number $l$ is greater than 1 , the $(110)_{\mathrm{Mo}_{5} \mathrm{Si}_{3}}$ planes coincide with the $\{1 \overline{1} 00\}_{\mathrm{Mo}_{5} \mathrm{Si}_{3} \mathrm{C}}$ planes at an interval of $l$ planes and so on. Relationships for the three sets of $\{1 \overline{1} 00\}_{\mathrm{Mo}_{5} \mathrm{Si}_{3} \mathrm{C}}$, namely, $(10 \overline{1} 0)_{\mathrm{Mo}_{5} \mathrm{Si}_{3} \mathrm{C}}(i=4)$, $(1 \overline{1} 00)_{\mathrm{Mo}_{5} \mathrm{Si}_{3} \mathrm{C}}(i=5)$, and $(0 \overline{1} 10)_{\mathrm{Mo}_{5} \mathrm{Si}_{3} \mathrm{C}}(i=6)$, with respect to $(1 \overline{1} 0)_{\mathrm{Mo}_{5} \mathrm{Si}_{3}}$ are similarly described by the following equations:

$$
\begin{array}{ll}
\tan \theta_{i}=\frac{d_{3} \cdot \sin \varphi_{i}-d_{4}}{d_{3} \cdot \cos \varphi_{i}} & (i=4,5, \text { and } 6) \\
\tan \theta_{i}{ }^{\prime}=\frac{d_{3} \cdot \sin \varphi_{i}+d_{4}}{d_{3} \cdot \cos \varphi_{i}} & (i=4,5, \text { and } 6)
\end{array}
$$

where $d_{3}=m \cdot d_{\{110\} \text { of } \mathrm{Mo}_{5} \mathrm{Si}_{3}}, d_{4}=n \cdot d_{\{1 \overline{1} 00\} \text { of } \mathrm{Mo}_{5} \mathrm{Si}_{3} \mathrm{C}}(m, n$ : positive integers $)$, and $\varphi_{i}=\varphi$ $(i=4), \varphi+60^{\circ}(i=5)$, and $\varphi+120^{\circ}(i=6)$.

Fig. 8(a) plots the $\varphi-\theta$ relationships for $\{1 \overline{1} 00\}_{\mathrm{Mo}_{5} \mathrm{Si}_{3} \mathrm{C}}$ with respect to $(110)_{\mathrm{Mo}_{5} \mathrm{Si}_{3}}$, assuming that both $k$ and $l$ are equal to 1 . The intersections between two $\varphi-\theta$ 
curves correspond to the conditions that two types of lattice misfits are simultaneously accommodated except for cases where one set of $\{1 \overline{1} 00\}_{\mathrm{Mo}_{5} \mathrm{Si}_{3} \mathrm{C}}$ is parallel to $(110)_{\mathrm{Mos}_{5} \mathrm{~S}_{3}}$; i.e., at the coordinates $(\varphi, \theta)$ of $\left(0^{\circ}, 0^{\circ}\right)$ and $\left(60^{\circ}, 180^{\circ}\right)$ seen in Fig. $8(\mathrm{a})$. In the $\varphi-\theta$ plots with respect to $(110)_{\mathrm{Mo}_{5} \mathrm{~S}_{3}}$ shown in Fig. 8(a), four intersections (points (I)-(IV)) exist at the coordinates $(\varphi, \theta)$ of (I): $\left(2.8^{\circ}, 32.8^{\circ}\right)$, (II): $\left(9.8^{\circ}, 69.8^{\circ}\right)$, (III): $\left(50.2^{\circ}, 110.2^{\circ}\right)$, and (IV): $\left(57.2^{\circ}, 147.2^{\circ}\right)$. Intersections (I) and (IV) are geometrically equivalent with a mirror relationship with respect to the $(110)_{\mathrm{Mo}_{5} \mathrm{Si}_{3}}$ plane, and the same holds for intersections (II) and (III). Only intersections (I) and (II) are sufficient for consideration. The repeat distances $\mathrm{OP}_{1}$ for intersections (I) and (II) are calculated as 1.26 and $0.728 \mathrm{~nm}\left(=a_{\mathrm{Mo}_{5} \mathrm{Si}_{3} \mathrm{C}}\right)$, respectively, which suggests that the condition for intersection (II) is preferred because of higher lattice coincidence. The ( $\varphi$, $\theta)$ coordinate $\left(11.6^{\circ}, 71.6^{\circ}\right)$ for the observed orientation relationship of $(2 \overline{1} 0)_{\mathrm{Mos}_{5} \mathrm{Si}_{3}} / /$ $(1 \overline{1} 00)_{\mathrm{Mog}_{5} \mathrm{~S}_{3} \mathrm{C}}$ is quite close to intersection (II) with a minor deviation of $\sim 2^{\circ}$.

It is reasonable to simultaneously consider the lattice misfit with respect to the $(1 \overline{1} 0)_{\mathrm{Mos}_{5} \mathrm{~S}_{3}}$ planes in addition to the $(110)_{\mathrm{Mo}_{5} \mathrm{Si}_{3}}$ planes discussed previously according to the four-fold symmetry along the $[001]_{\mathrm{Mo}_{5} \mathrm{Si}_{3}}$ axis. Various $(k, l)$ and $(m, n)$ pairs of relatively small positive integers are considered since relatively high coherence can be achieved when $k, l, m$, and $n$ are small (see supplementary material). Figs. 8(b) and (c) plot the $\varphi-\theta$ relationships with respect to the $(1 \overline{1} 0)_{\mathrm{Mo}_{5} \mathrm{Si}_{3}}$ planes for the $(m, n)$ pairs of $(1$, 1) and (1,3), respectively. Among various intersections between different curves in Figs. 8(b) and (c), the intersection between the $\varphi-\theta_{4}{ }^{\prime}$ and $\varphi-\theta_{6}$ curves with the $(m, n)$ pair of $(1,3)$ has the coordinate $\left(11.8^{\circ}, 71.8^{\circ}\right)$ and is hereafter referred to as intersection $(\mathrm{X})$. 
The experimentally observed $(\varphi, \theta)$ coordinate $\left(11.6^{\circ}, 71.6^{\circ}\right)$ is located between intersections (II) and (X) with less than $2^{\circ}$ deviation. No other points have such a high coincidence of intersections in the tilt angle range between $0^{\circ}$ and $30^{\circ}$ (see supplementary material). Thus, it can be concluded that the observed orientation relationship of $(2 \overline{1} 0)_{\mathrm{Mo}_{5} \mathrm{~S}_{3}} / /(1 \overline{1} 00)_{\mathrm{Mo}_{5} \mathrm{Si}_{3} \mathrm{C}}$ is selected mainly because it can simultaneously minimize four types of $\{110\}_{\mathrm{Mo}_{5} \mathrm{~S}_{3}}\{11 \overline{1} 00\}_{\mathrm{Mos}_{5} \mathrm{~S}_{3} \mathrm{C}}$ lattice misfits.

Once the tilt angle $\varphi$ is fixed, the intersections between the $\varphi-\theta$ curves and the vertical line of the fixed $\varphi$ provide the interface inclination angles $\theta$ with relatively low energies achieved by minimizing at least one of the $\{110\}_{\mathrm{Mos}_{5} \mathrm{~S}_{3}}\{1 \overline{1} 00\}_{\mathrm{Mos}_{5} \mathrm{~S}_{3} \mathrm{C}}$ lattice misfits. Fig. 8(d) shows the superposed image of Fig. 8(a) and Fig. 8(b) plotted in the tilt angle range from $0^{\circ}$ to $30^{\circ}$. In the same way, Fig $8(\mathrm{e})$ shows the superposed image of Fig. 8(a) and Fig. 8(c). In addition to the intersections in Figs. 8(a) and (b), there is an intersection between two $\varphi-\theta$ curves, $\varphi-\theta_{1}$ ' and $\varphi-\theta_{5}$ located near the observed tilt angle $\varphi$ of $11.6^{\circ}$ in Fig. 8(d). This intersection suggests that the $\mathrm{Mo}_{5} \mathrm{Si}_{3} / \mathrm{Mo}_{5} \mathrm{Si}_{3} \mathrm{C}$ interfaces with the macroscopic inclination angle of $\sim 5^{\circ}$ are stable interfaces with relatively low energy because two types of lattice misfits are minimized simultaneously at the inclination angle. In fact, $\mathrm{Mo}_{5} \mathrm{Si}_{3} / \mathrm{Mo}_{5} \mathrm{Si}_{3} \mathrm{C}$ interfaces with the macroscopic inclination angle $\theta$ of $\sim 5^{\circ}$ are also frequently observed (see supplementary material).

A similar analysis can be applied to the $\mathrm{MoSi}_{2} / \mathrm{Mo}_{5} \mathrm{Si}_{3} \mathrm{C}$ interfaces where three

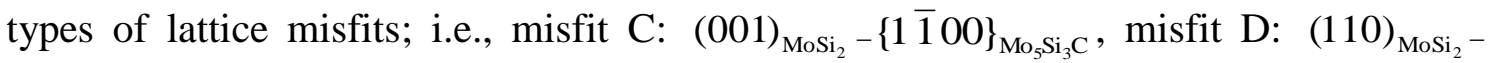
$\{1 \overline{1} 00\}_{\mathrm{Mos}_{5} \mathrm{~S}_{3} \mathrm{C}}$, and misfit E: $(1 \overline{1} 0)_{\mathrm{MoSi}_{2}-}(0002)_{\mathrm{Mos}_{5} \mathrm{~S}_{3} \mathrm{C}}$ should be considered. Misfits C and $\mathrm{D}$ can be accommodated by tilting one of the crystals with respect to the other. The $\varphi-\theta$ relationships with respect to misfits $\mathrm{C}$ and $\mathrm{D}$ are also described by Eqs. (5)-(8) 
where $\quad d_{1}=p \cdot d_{(001) \text { of } \mathrm{MoSi}_{2}}, \quad d_{2}=q \cdot d_{\{1 \overline{1} 00\} \text { of } \mathrm{Mo}_{5} \mathrm{Si}_{3} \mathrm{C}}, \quad d_{3}=r \cdot d_{\{110\} \text { of } \mathrm{MoSi}_{2}}, \quad$ and $d_{4}=s \cdot d_{\{1 \overline{1} 00\} \text { of } \mathrm{Mo}_{5} \mathrm{Si}_{3} \mathrm{C}}(p, q, r$, and $s$ are positive integers). Fig. 9 shows several $\varphi-\theta$ relationships with respect to misfits $\mathrm{C}$ and D. One intersection (point (III)) for misfit $\mathrm{C}$ is located near the vertical line corresponding to the observed tilt angle $\varphi$ of $11.6^{\circ}$ at the $(\varphi, \theta)$ coordinate $\left(11.9^{\circ}, 161.9^{\circ}\right)$, when the $(p, q)$ pair is $(1,2)$ as shown in Fig. $9(\mathrm{~b})$. Two intersections (points (VII) and (VIII)) for misfit D possess tilt angle $\varphi$ values close to the observed value when the $(r, s)$ pair is equal to $(1,1)$ (Fig. 9(c)). These results suggest that the interface inclination angles of $161.9^{\circ}$ (point (III)), $100.3^{\circ}$ (point (VII)), and $71.9^{\circ}$ (point (VIII)) are preferentially selected because they possess relatively low interface energies. The macroscopic inclinations of $\sim 72^{\circ}$ and $\sim 162^{\circ}$ are actually observed (see supplementary material). Therefore, it is concluded that the preferred interface inclination angles are selected so as to effectively minimize the interface energy related to lattice misfits.

\subsection{High-temperature strength}

Although the operative deformation modes has not been completely characterized in the present study, all three component phases are confirmed to deform plastically at $1000{ }^{\circ} \mathrm{C}$, where the flow stress starts to decrease from the maximum value at $\sim 1 \%$ plastic strain. As shown in Fig. 5(b), plastic deformation of $\mathrm{Mo}_{5} \mathrm{Si}_{3}$ and $\mathrm{Mo}_{5} \mathrm{Si}_{3} \mathrm{C}$ single crystals with corresponding loading axis orientation has not been reported so far at $1000{ }^{\circ} \mathrm{C}[14,15]$. Moreover, yield stress values for the three- and two-phase eutectic composites are much higher than those of $\mathrm{MoSi}_{2}$ single crystals at all tested temperatures, especially below $1200{ }^{\circ} \mathrm{C}$. Thus, it is reasonable to consider that plastic 
deformation starts in the $\mathrm{MoSi}_{2}$ matrix and then transmits to the $\mathrm{Mo}_{5} \mathrm{Si}_{3}$ and $\mathrm{Mo}_{5} \mathrm{Si}_{3} \mathrm{C}$ rods. As described in section 3.1, the average thickness of the $\mathrm{MoSi}_{2}$ matrix measured along two orthogonal directions decreases with the existence of the $\mathrm{Mo}_{5} \mathrm{Si}_{3} \mathrm{C}$ rods compared with the average thickness in the two-phase counterpart. Therefore, higher yield strength for the three-phase composites is considered to reflect mainly the difference in average thickness of the $\mathrm{MoSi}_{2}$ matrix and also the difference in stress level that activates dislocation sources in $\mathrm{Mo}_{5} \mathrm{Si}_{3} \mathrm{C}$ and $\mathrm{Mo}_{5} \mathrm{Si}_{3}$ rods.

\section{Conclusions}

1. DS ingots of the $\mathrm{MoSi}_{2} / \mathrm{Mo}_{5} \mathrm{Si}_{3} / \mathrm{Mo}_{5} \mathrm{Si}_{3} \mathrm{C}$ three-phase eutectic composites exhibit a homogeneous script lamellar structure. $\mathrm{Mo}_{5} \mathrm{Si}_{3}$ and $\mathrm{Mo}_{5} \mathrm{Si}_{3} \mathrm{C}$ phases individually form interconnected networks that extend along the GD in the $\mathrm{MoSi}_{2}$ matrix and maintain $[1 \overline{1} 0]_{\mathrm{MoSi}_{2}}, \quad[001]_{\mathrm{Mo}_{5} \mathrm{Si}_{3}}$, and $[0001]_{\mathrm{Mo}_{5} \mathrm{Si}_{3} \mathrm{C}}$ approximately parallel to the GD.

2. The three component phases possess a distinct orientation relationship in the DS three-phase eutectic composites. The orientation relationship between $\mathrm{Mo}_{5} \mathrm{Si}_{3}$ and $\mathrm{Mo}_{5} \mathrm{Si}_{3} \mathrm{C}$ in the DS three-phase eutectic composites is summarized as $(2 \overline{1} 0)_{\mathrm{MoS}_{5} \mathrm{Si}_{3}} / /$ $(1 \overline{1} 00)_{\mathrm{Mo}_{5} \mathrm{Si}_{3} \mathrm{C}}$ and $[001]_{\mathrm{Mo}_{5} \mathrm{Si}_{3}} / /[0001]_{\mathrm{Mo}_{5} \mathrm{Si}_{3} \mathrm{C}}$, whereas that between $\mathrm{MoSi}_{2}$ and $\mathrm{Mo}_{5} \mathrm{Si}_{3}$ is $(110)_{\mathrm{MoSi}_{2}} / /(1 \overline{1} 0)_{\mathrm{Mo}_{5} \mathrm{Si}_{3}}$ and $[1 \overline{1} 0]_{\mathrm{MoSi}_{2}} / /[001]_{\mathrm{Mo}_{5} \mathrm{Si}_{3}}$, the latter of which is identical to what is observed in the two-phase counterparts. The orientation relationship of $\mathrm{Mo}_{5} \mathrm{Si}_{3} \mathrm{C}$ in the DS three-phase composites is selected to effectively accommodate lattice misfits between $\{110\}_{\mathrm{Mo}_{5} \mathrm{Si}_{3}}$ and $\{1 \overline{1} 00\}_{\mathrm{Mo}_{5} \mathrm{Si}_{3} \mathrm{C}}$ at the $\mathrm{Mo}_{5} \mathrm{Si}_{3} / \mathrm{Mo}_{5} \mathrm{Si}_{3} \mathrm{C}$ interfaces parallel to $(2 \overline{1} 0)_{\mathrm{Mo}_{5} \mathrm{Si}_{3}}$ and $(1 \overline{1} 00)_{\mathrm{Mo}_{5} \mathrm{Si}_{3} \mathrm{C}}$.

3. High-temperature strength of the DS three-phase eutectic composites is higher than 
that of the binary two-phase counterparts, especially below $1200{ }^{\circ} \mathrm{C}$. This is because of the existence of the $\mathrm{Mo}_{5} \mathrm{Si}_{3} \mathrm{C}$ phase and the resultant microstructure refinement of the $\mathrm{MoSi}_{2}$ matrix.

Acknowledgement

This work was supported by the Advanced Low Carbon Technology Research and Development Program (ALCA) of the Japan Science and Technology Agency (JST), the Elements Strategy Initiative for Structural Materials (ESISM) from Ministry of Education, Culture, Sports, Science and Technology (MEXT) Japan, and JSPS KAKENHI (Nos. 15H02300 and 15K14162).

References

[1] K. Ito, H. Inui, Y. Shirai, M. Yamaguchi, Plastic deformation of $\mathrm{MoSi}_{2}$ single crystals, Philos. Mag. A 72 (1995) 1075-1097.

[2] S.A. Maloy, T.E. Mitchell, A.H. Heuer, High temperature plastic anisotropy in $\mathrm{MoSi}_{2}$ single crystals, Acta Mater. 43 (1995) 657-668.

[3] H. Inui, K. Ishikawa, M. Yamaguchi, Effects of alloying elements on plastic deformation of single crystals of $\mathrm{MoSi}_{2}$, Intermet. 8 (2000) 1131-1145.

[4] R. Mitra, Mechanical behavior and oxidation resistance of structural silicides, Int. Mater. Rev. 51 (2006) 13-64.

[5] R. Gibala, A.K. Ghosh, D.C. Van Aken, D.J. Srolovitz, A. Basu, H. Chang, D.P. Mason, W. Yang, Mechanical behavior and interface design of $\mathrm{MoSi}_{2}$-based alloys and composites, Mater. Sci. Eng. A 155 (1992) 147-158.

[6] A.K. Vasudevan, J.J. Petrovic, A comparative overview of molybdenum disilicide 
composites, Mater. Sci. Eng. A 155 (1992) 1-17.

[7] K. Fujiwara, H. Matsunoshita, Y. Sasai, K. Kishida, H. Inui, Effects of ternary additions on the microstructure and thermal stability of directionally-solidified $\mathrm{MoSi}_{2} / \mathrm{Mo}_{5} \mathrm{Si}_{3}$ eutectic composites, Intermet. 52 (2014) 72-85.

[8] K. Fujiwara, Y. Sasai, K. Kishida, H. Inui, Effects of ternary additions on the microstructure of directionally-solidified $\mathrm{MoSi}_{2} / \mathrm{Mo}_{5} \mathrm{Si}_{3}$ eutectic composites, MRS Proc. 1516 (2013) 189-194.

[9] D.P. Mason, D.C. Van Aken, J.F. Mansfield, On the microstructure and crystallography of directionally solidified $\mathrm{MoSi}_{2}-\mathrm{Mo}_{5} \mathrm{Si}_{3}$ eutectics, Acta Metall. Mater. 43 (1995) 1189-1199.

[10] D.P. Mason, D.C. Van Aken, On the creep of directionally solidified $\mathrm{MoSi}_{2}-\mathrm{Mo}_{5} \mathrm{Si}_{3}$ eutectics, Acta Metall. Mater. 43 (1995) 1201-1210.

[11] Y. Sasai, A. Inoue, K. Fujiwara, K. Kishida, H. Inui, Plastic deformation of directionally-solidified $\mathrm{MoSi}_{2} / \mathrm{Mo}_{5} \mathrm{Si}_{3}$ eutectic composites, MRS Proc. 1516 (2013) 195-200.

[12] H. Matsunoshita, K. Fujiwara, Y. Sasai, Y. Kondo, K. Kishida, H. Inui, Microstructures and mechanical properties of $\mathrm{MoSi}_{2} / \mathrm{Mo}_{5} \mathrm{Si}_{3} / \mathrm{Mo}_{5} \mathrm{Si}_{3} \mathrm{C}$ ternary eutectic composite, MRS Proc. 1760 (2015) 169-174.

[13] P. Villars, H. Okamoto, K. Cenzual (Eds.), ASM alloy phase diagram database, ASM Int, Materials 2006-2013. $\langle$ http://www1.asminternational.org/AsmEnterprise/APD>.

[14] K. Yoshimi, M.H. Yoo, A.A. Wereszczak, S.M. Borowicz, E.P. George, E. Miura, S. Hanada, Deformation behavior of $\mathrm{Mo}_{5} \mathrm{Si}_{3}$ single crystal at high temperatures, Mater. Sci. Eng. A 329-331 (2002) 228-234. 
[15] T. Hayashi, K. Ito, K. Tanaka, Physical and mechanical properties of single crystals of the $\mathrm{Mo}_{5} \mathrm{Si}_{3} \mathrm{C}$ phase, Intermet. 11 (2003) 835-840.

[16] H. Inui, M. Yamaguchi, Deformation mechanisms of transition-metal disilicides with the hexagonal C40 structure, Intermet. 9 (2009) 857-862.

[17] K. Ito, T. Yano, T. Nakamoto, H. Inui, M. Yamaguchi, Plastic deformation of single crystals of $\mathrm{WSi}_{2}$ with the $\mathrm{C} 11_{\mathrm{b}}$ structure, Acta Mater. 47 (1999) 917-949.

[18] H. Inui. M. Moriwaki, N. Okamoto, M. Yamaguchi, Plastic deformation of single crystals of $\mathrm{TiSi}_{2}$ with the C54 structure, Acta Mater. 51 (2003) 1409-1420.

[19] K. Kishida, M. Fujiwara, H. Adachi, K. Tanaka, H. Inui, Plastic deformation of single crystals of $\mathrm{Ti}_{5} \mathrm{Si}_{3}$ with the hexagonal D8 8 structure, Acta Mater. 58 (2010) 846-857.

[20] Y. Mou, Intrinsic ledges at interphase boundaries and the crystallography of precipitate plates, Metall. Mater. Trans. A 25 (1994) 1905-1915. 

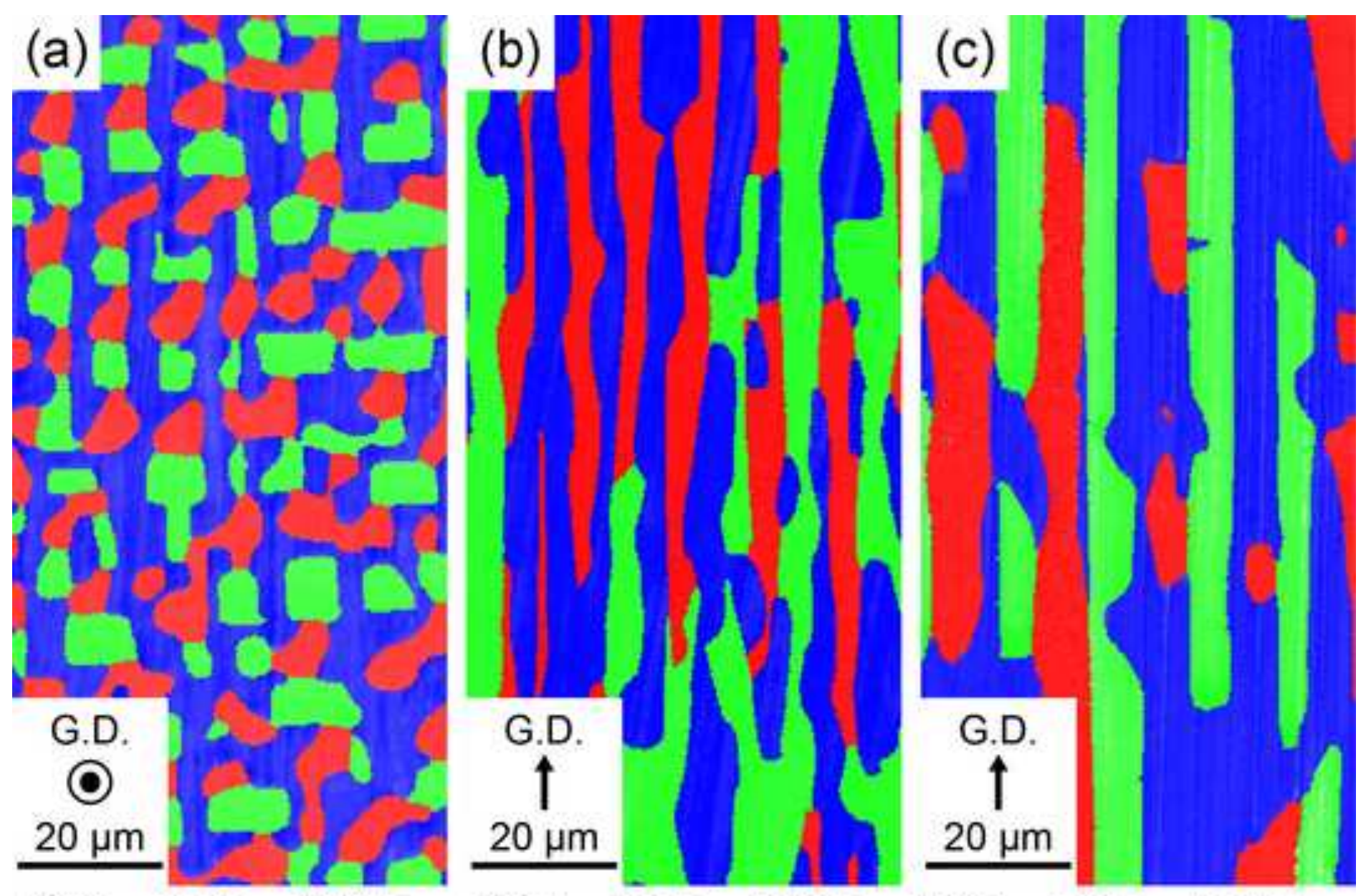

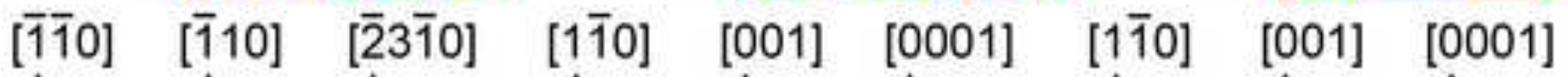

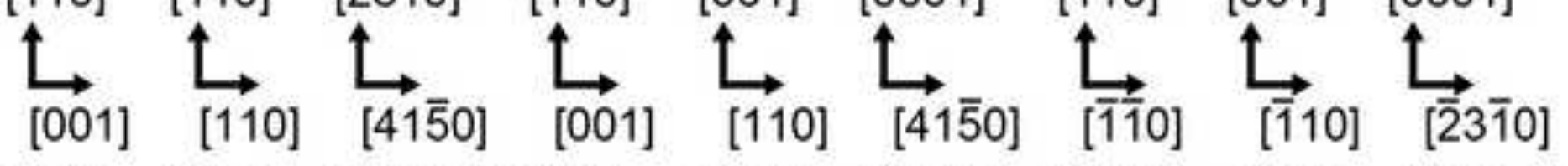
$\begin{array}{lllllllll}\mathrm{MoSi}_{2} & \mathrm{Mo}_{5} \mathrm{Si}_{3} & \mathrm{Mo}_{5} \mathrm{Si}_{3} \mathrm{C} & \mathrm{MoSi}_{2} & \mathrm{Mo}_{5} \mathrm{Si}_{3} & \mathrm{Mo}_{5} \mathrm{Si}_{3} \mathrm{C} & \mathrm{MoSi}_{2} & \mathrm{Mo}_{5} \mathrm{Si}_{3} & \mathrm{Mo}_{5} \mathrm{Si}_{3} \mathrm{C}\end{array}$
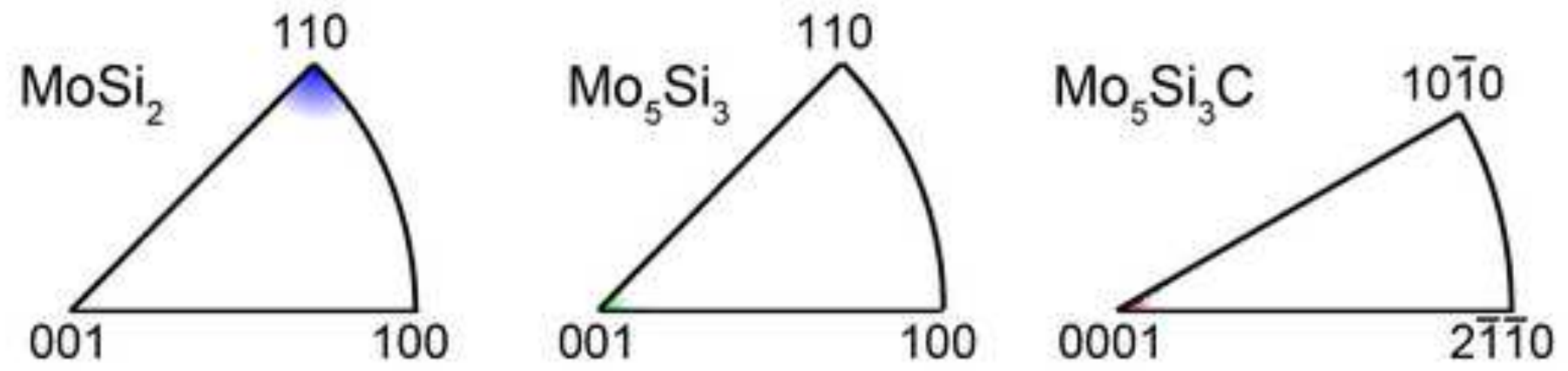


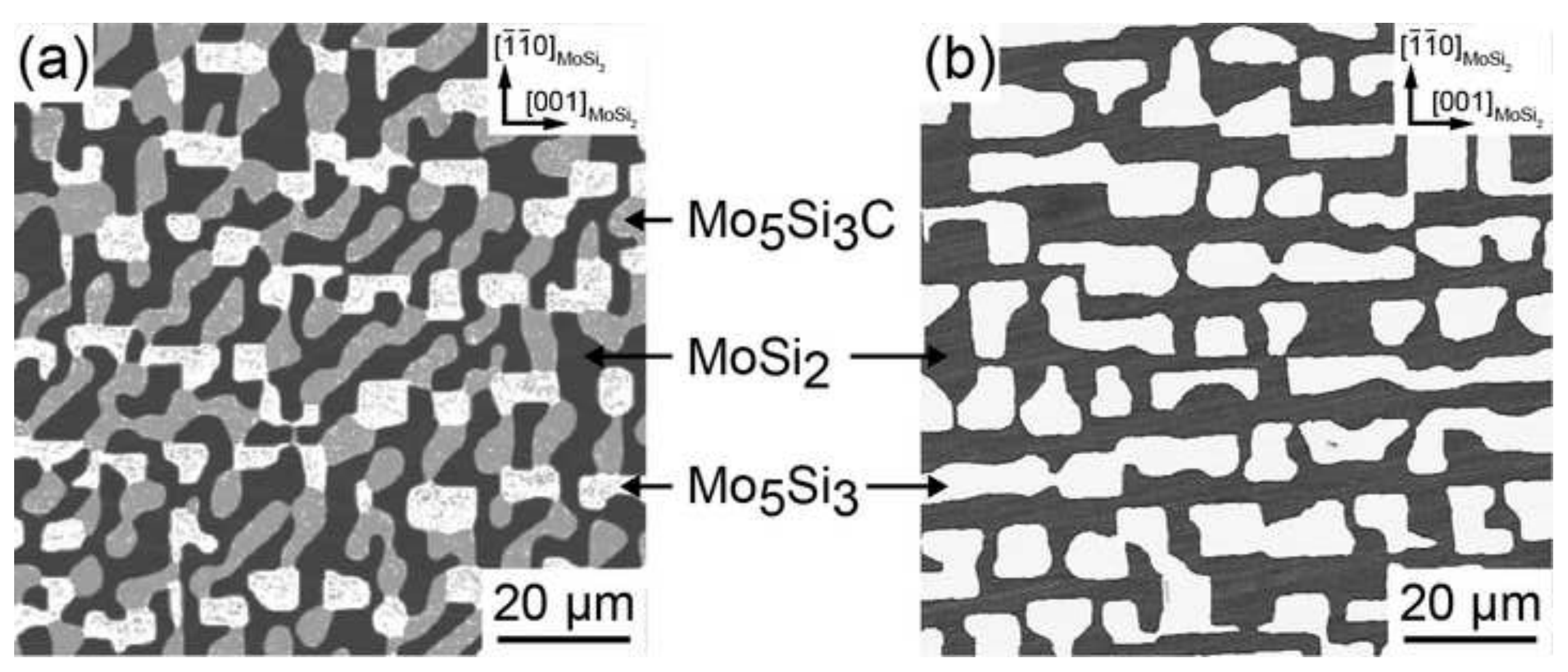


(a)

550

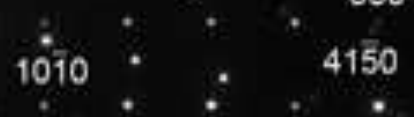

2110 .

$.2310 \quad 420$
$3 \frac{5}{30} \quad 3300$

\section{(c)}

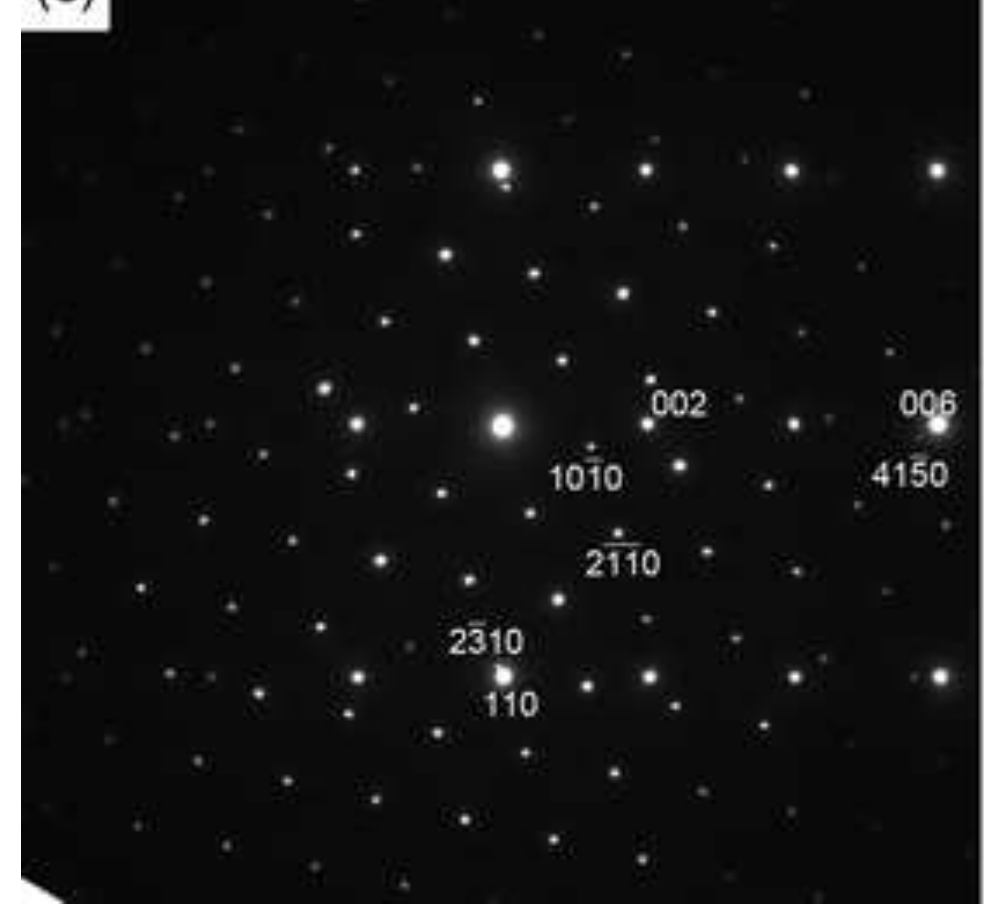

(b)

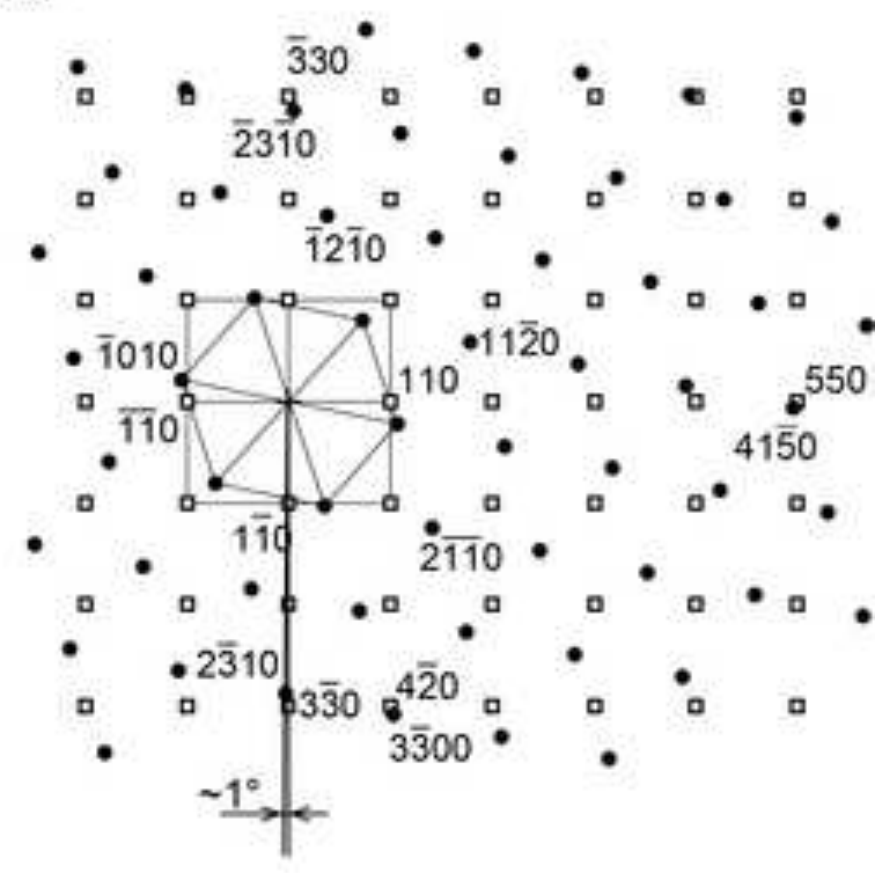

(d)

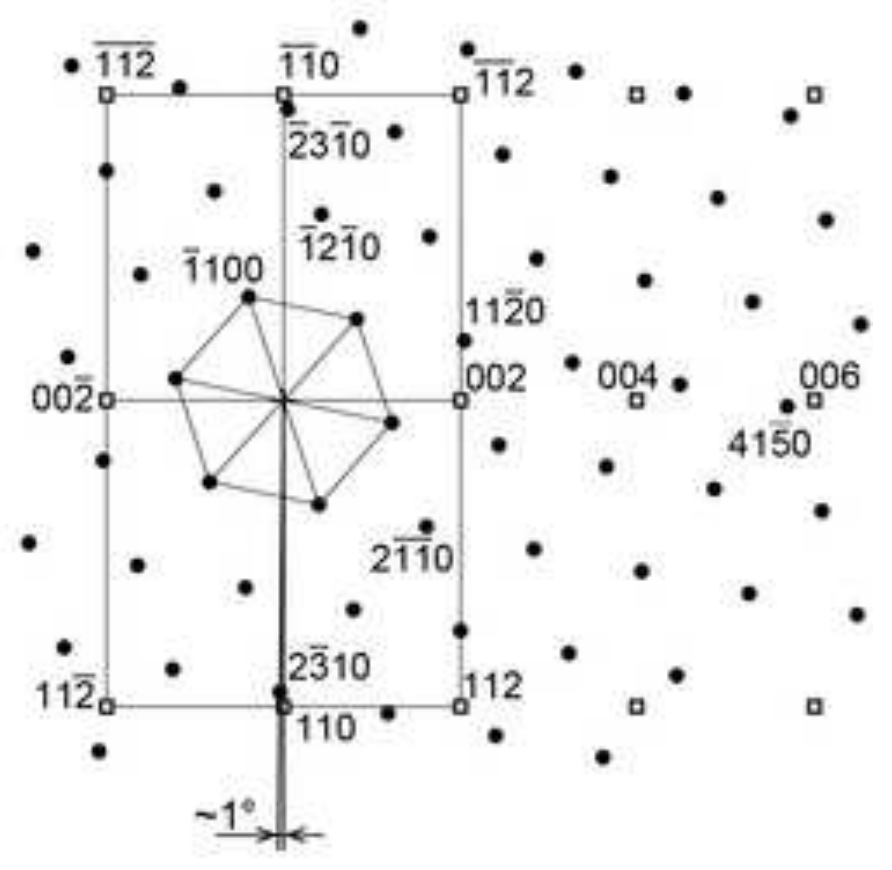


(a)

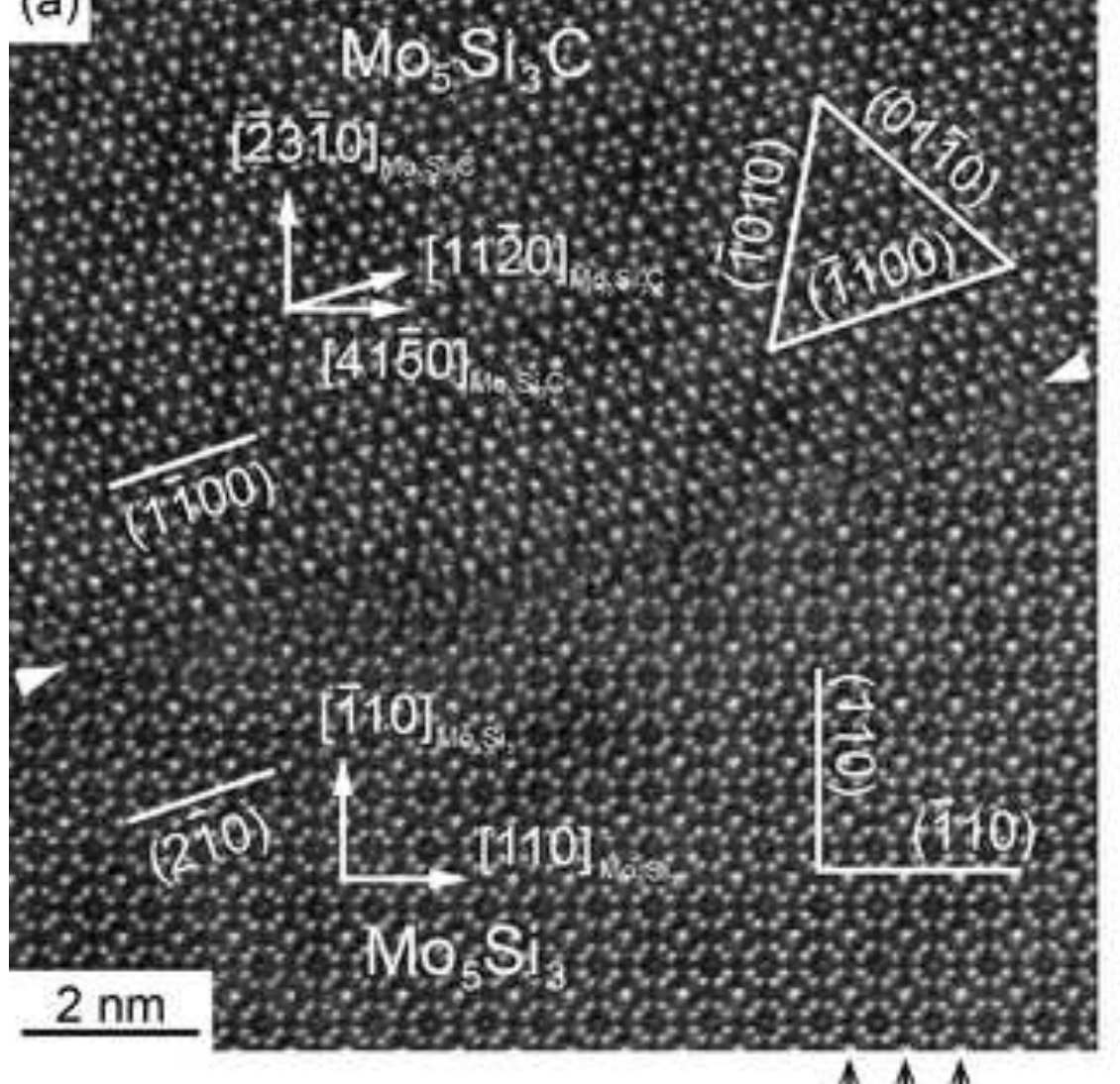

$\uparrow \uparrow \uparrow$ (b)

MosSC

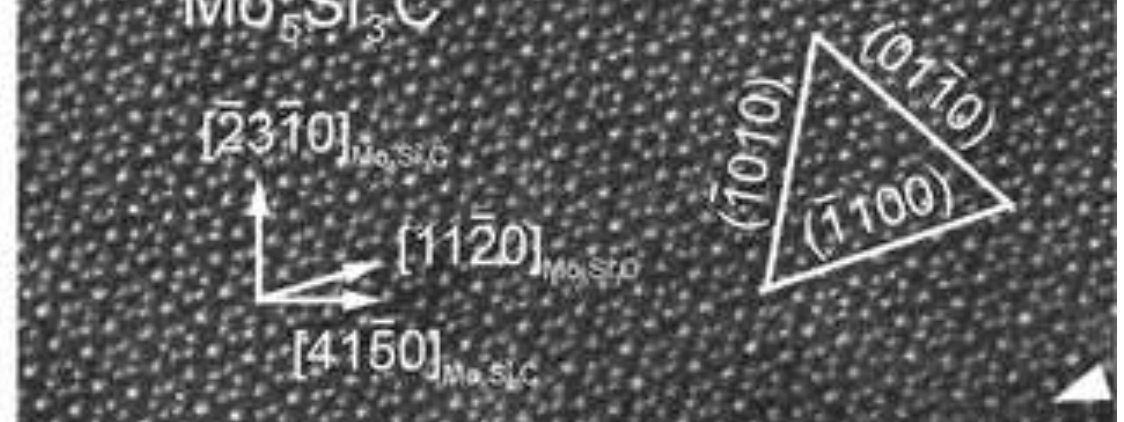

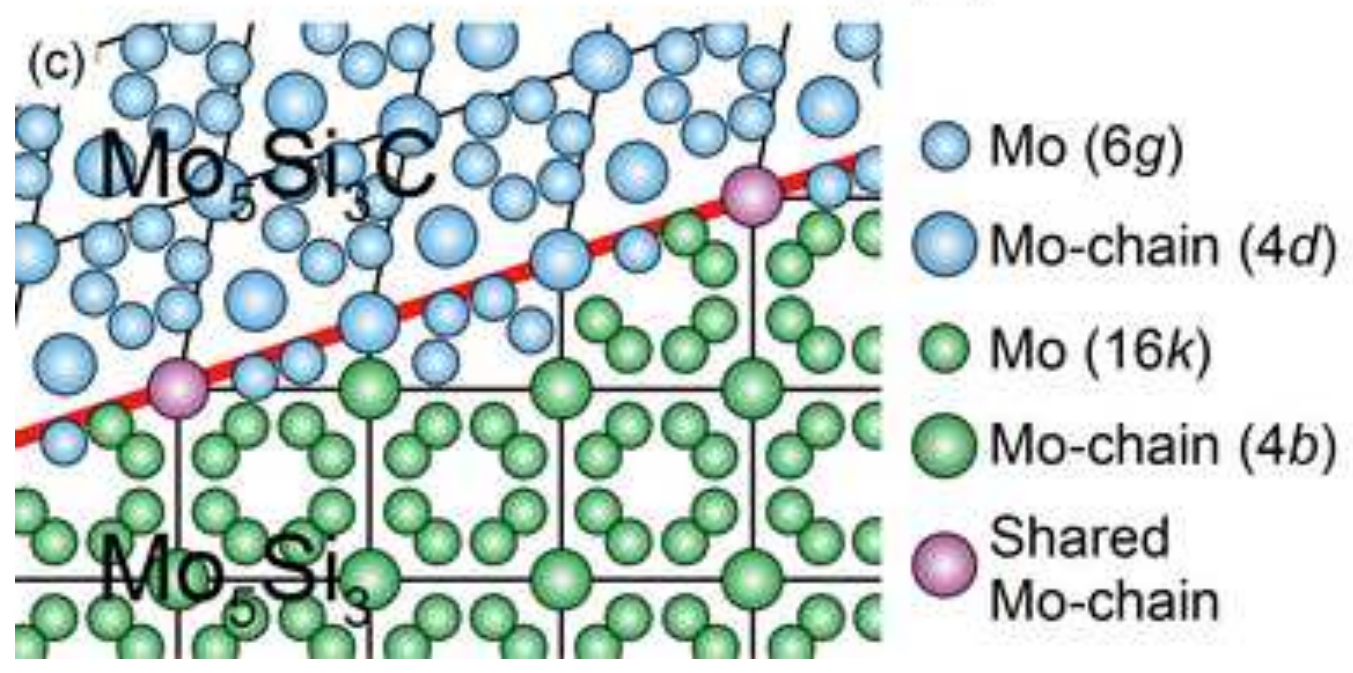

\section{[1T0]}

[0011 $\mathrm{MoSi}_{2}$

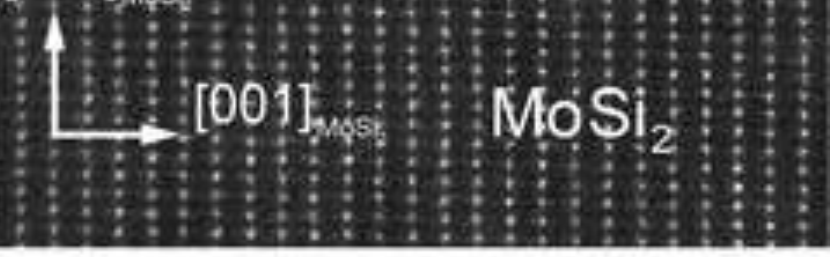


(a)
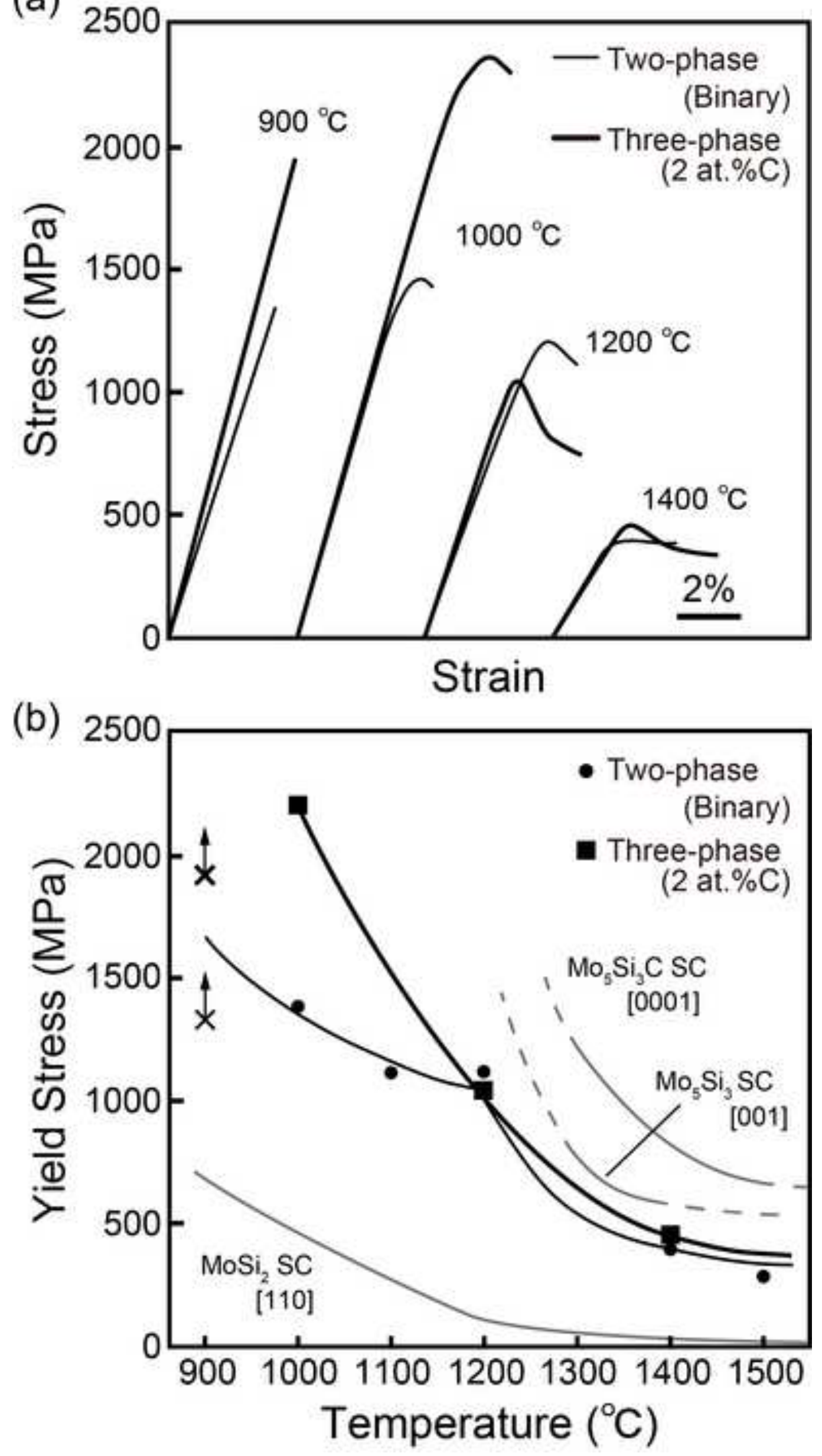

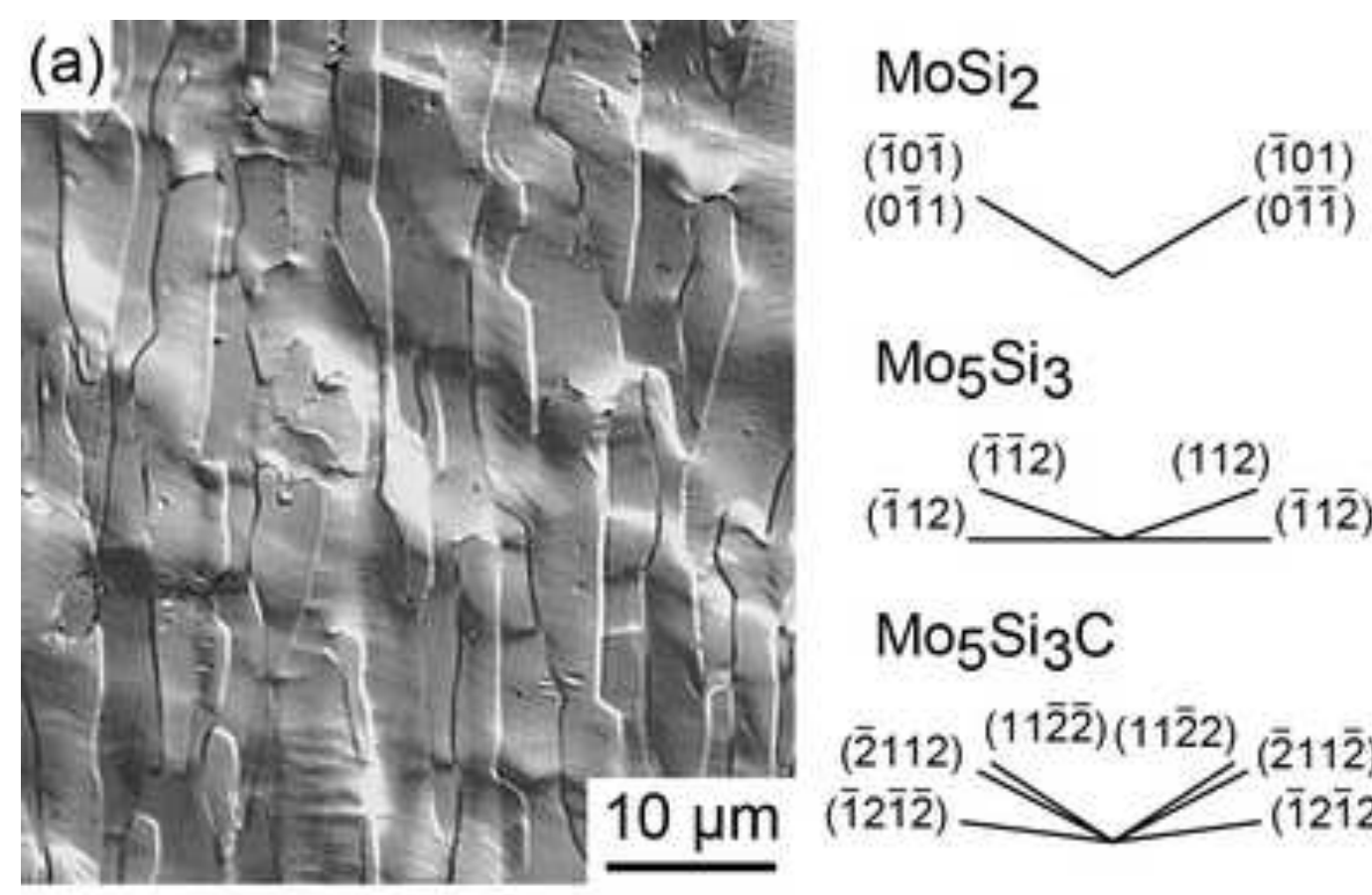

$\mathrm{Mo}_{5} \mathrm{Si}_{3}$

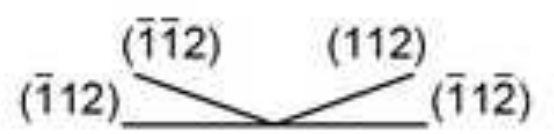

\section{$\mathrm{Mo}_{5} \mathrm{Si}_{3} \mathrm{C}$}

$(\overline{2} 112){ }^{(11 \overline{2} \overline{2})(11 \overline{2} 2)}(\overline{2} 11 \overline{2})$ $(\overline{1} 2 \overline{1} \overline{2}) \smile{ }_{(\overline{1} 2 \overline{1} 2)}$
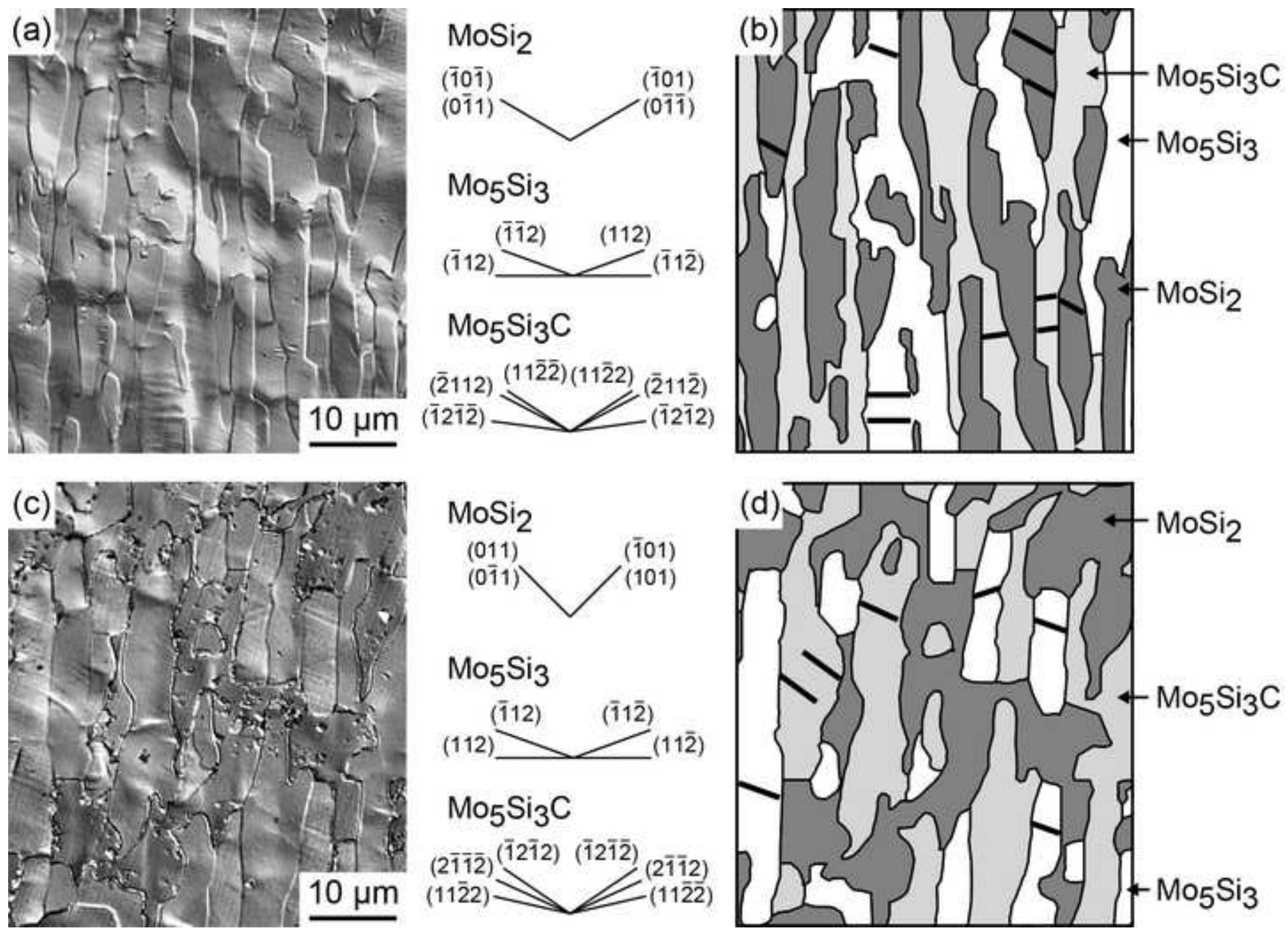

$\mathrm{Mo}_{5} \mathrm{Si}_{3} \mathrm{C}$
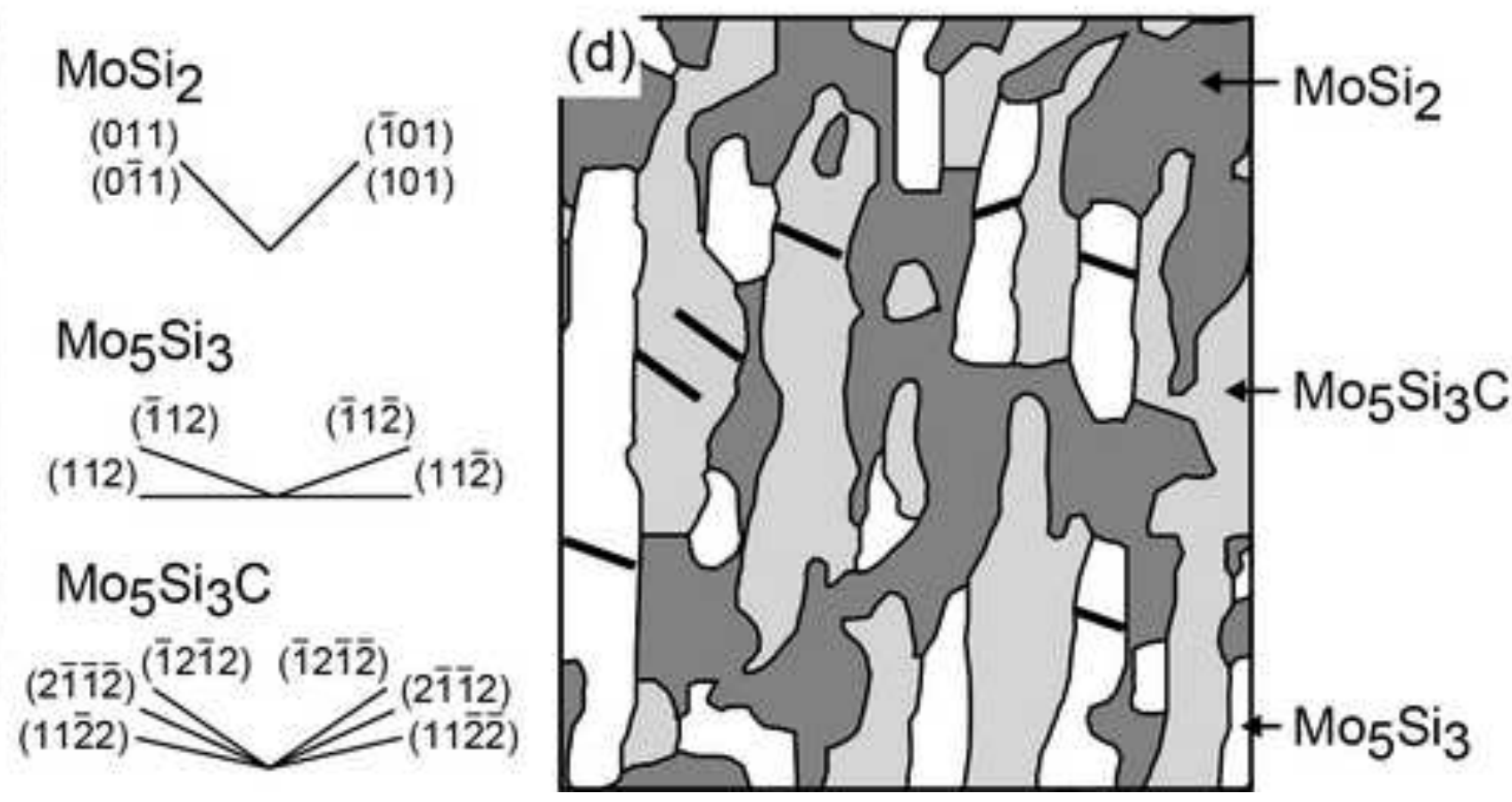
(a)

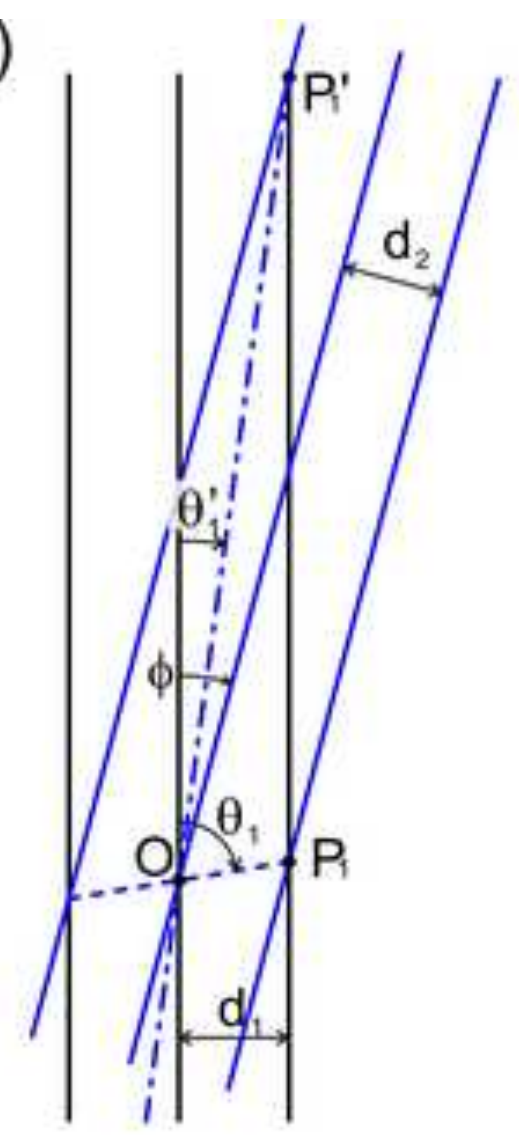

(b)

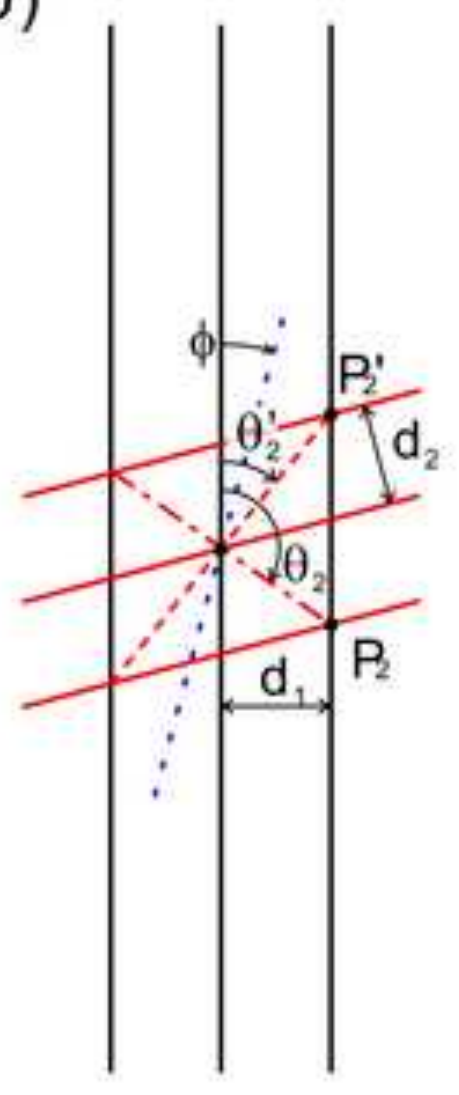

(c)

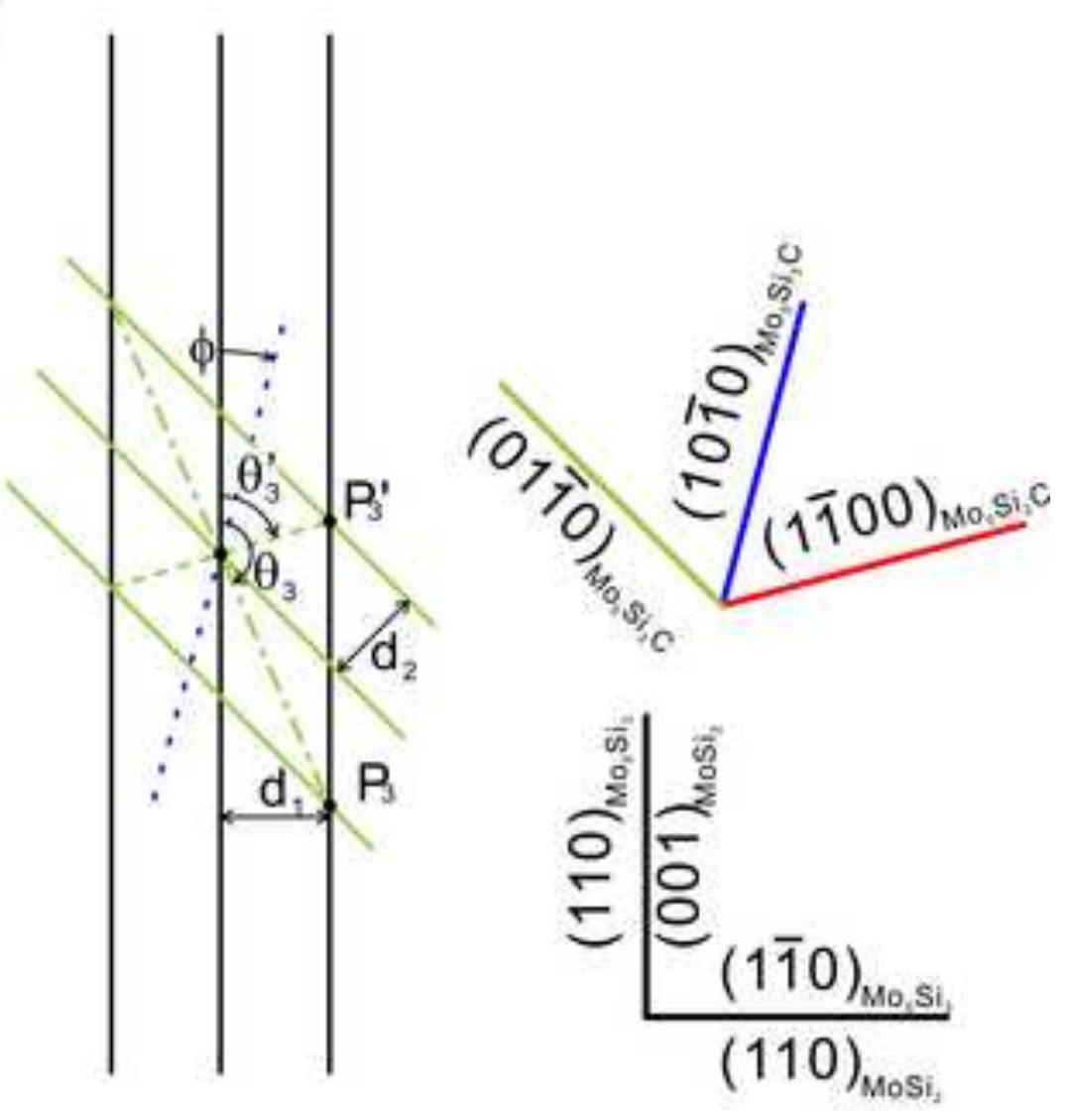

(d)

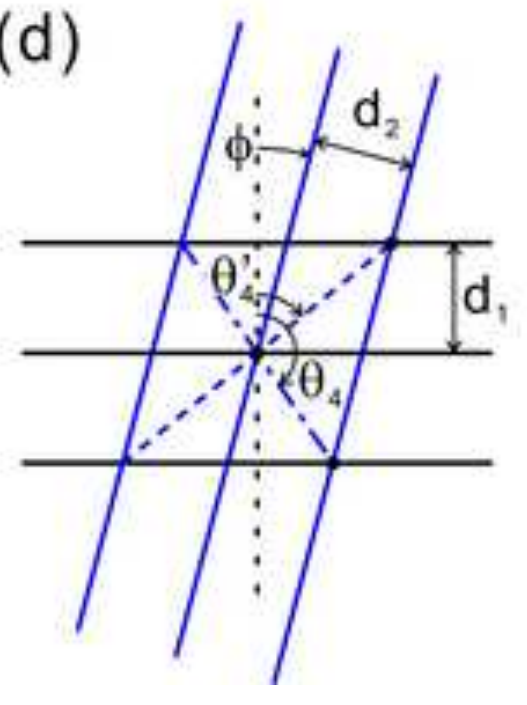

(e)

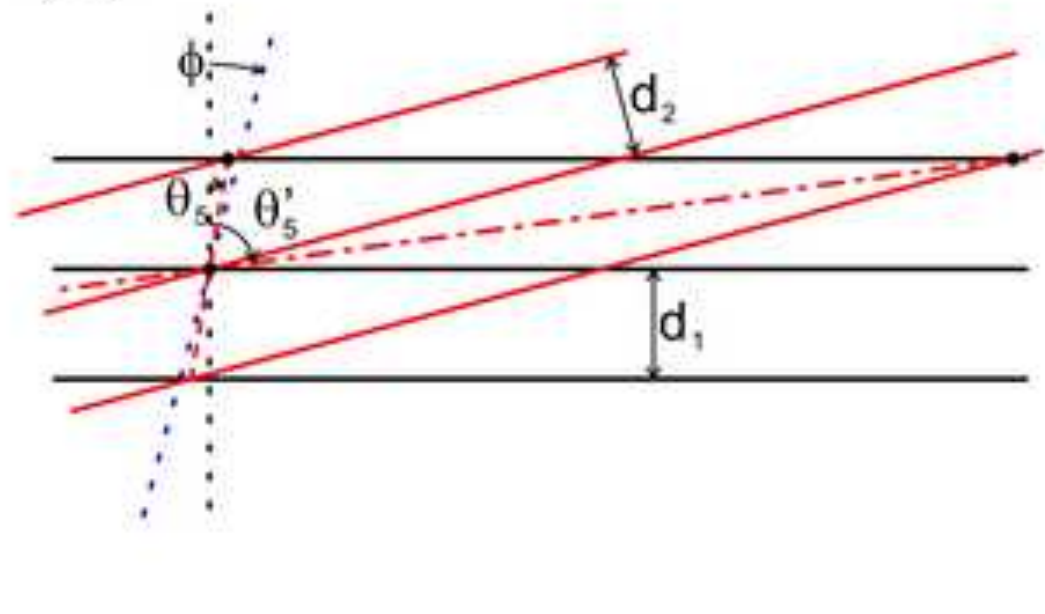

(f)

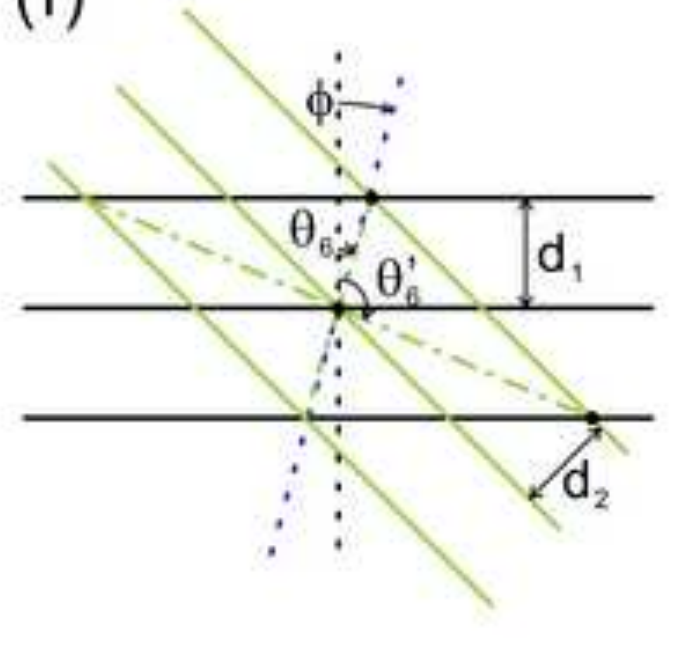


$\mathrm{Mo}_{5} \mathrm{Si}_{3}-\mathrm{Mo}_{5} \mathrm{Si}_{3} \mathrm{C}$ interface

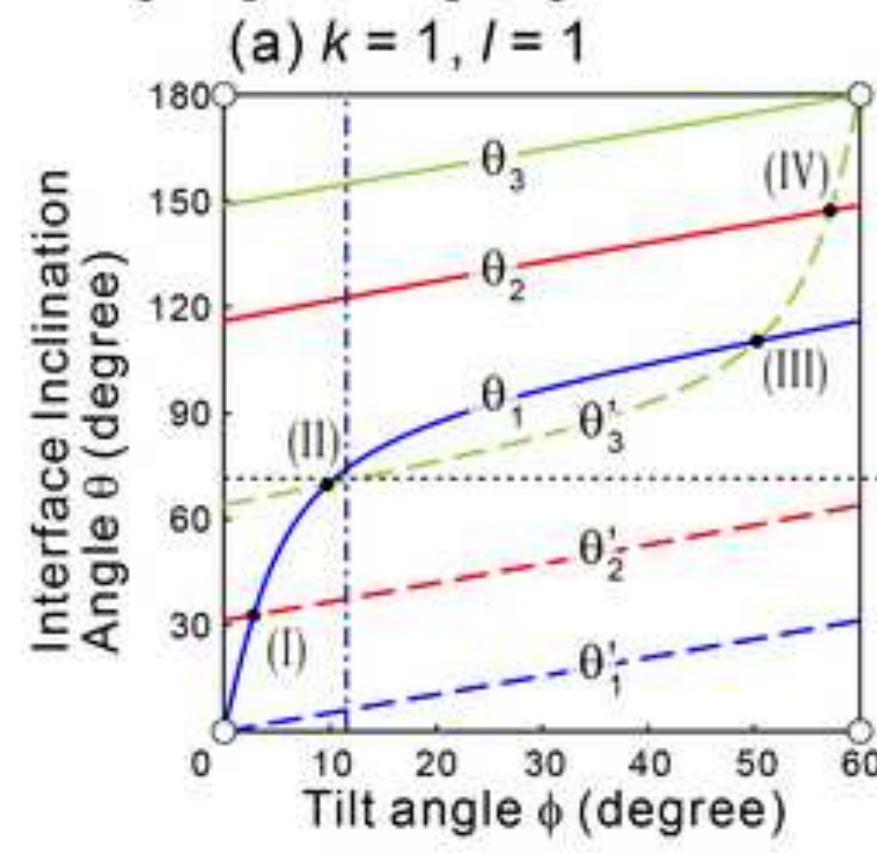

(b) $m=1, n=1$

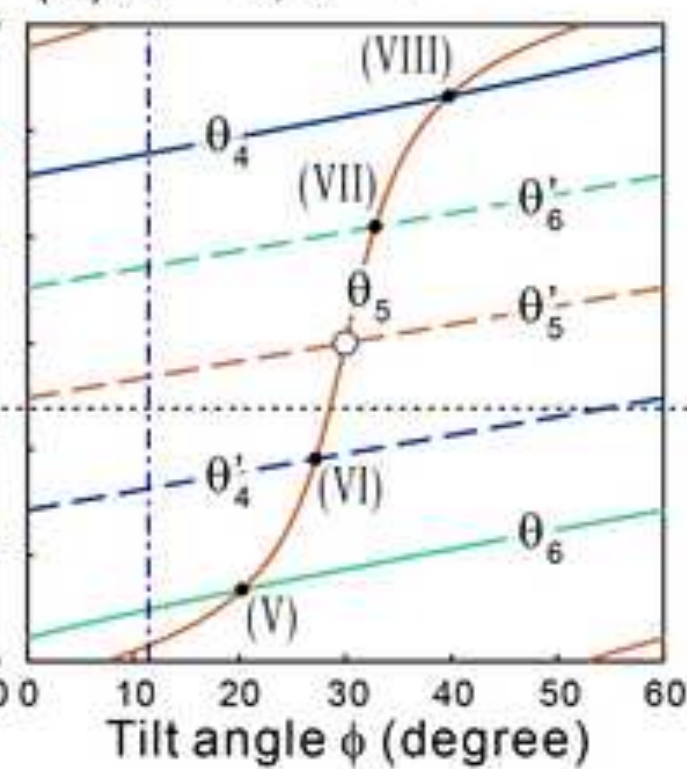

(c) $m=1, n=3$
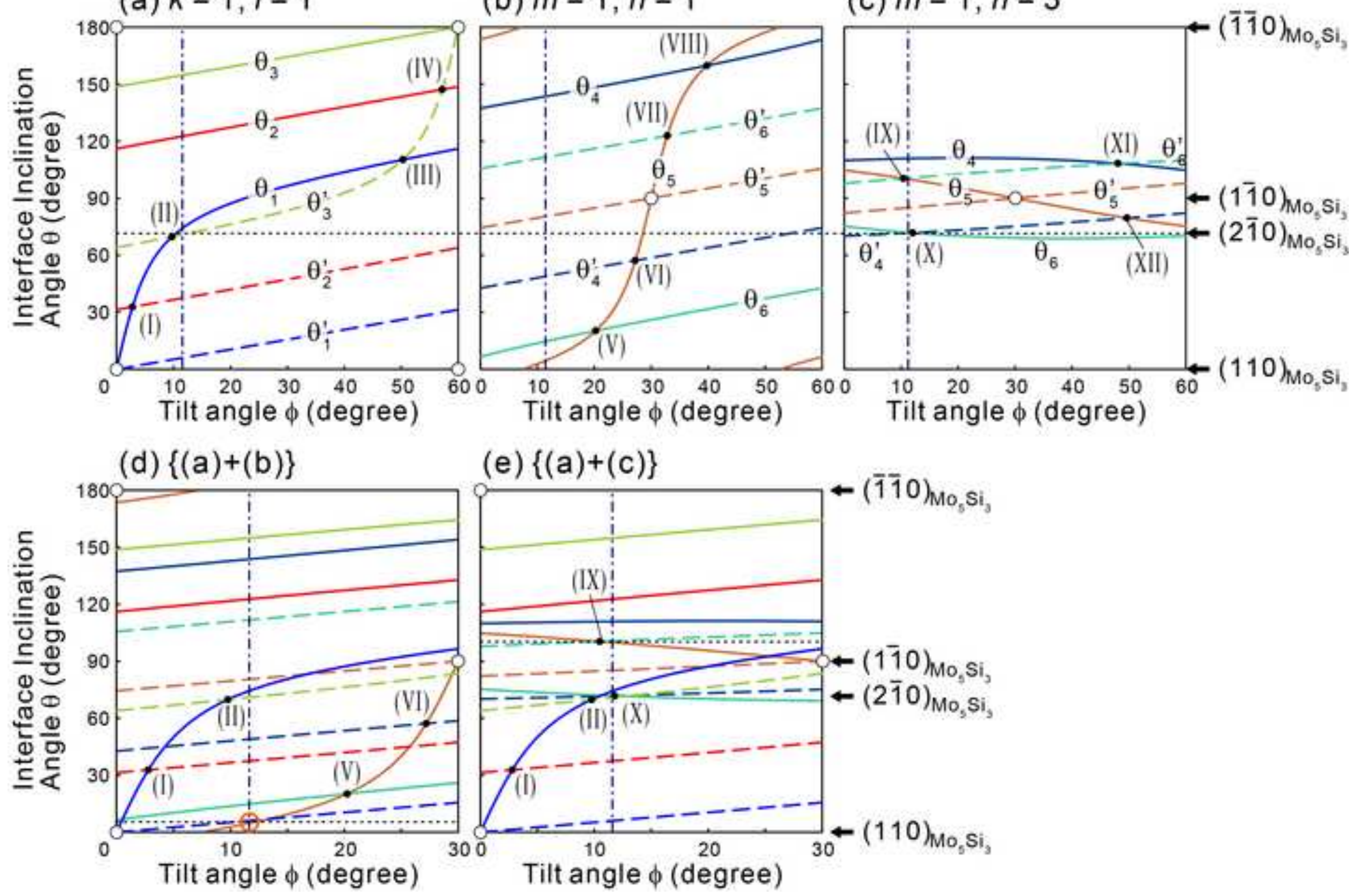

(e) $\{(\mathrm{a})+(\mathrm{c})\}$

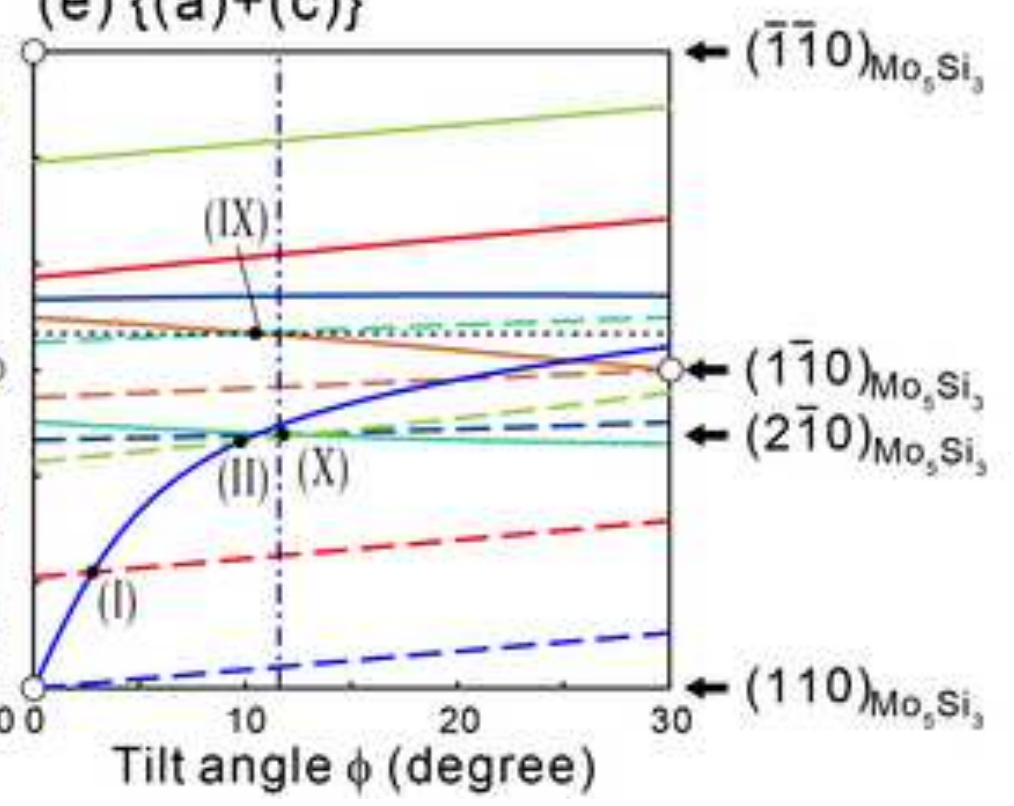




\section{$\mathrm{MoSi}_{2}-\mathrm{Mo}_{5} \mathrm{Si}_{3} \mathrm{C}$ interface}

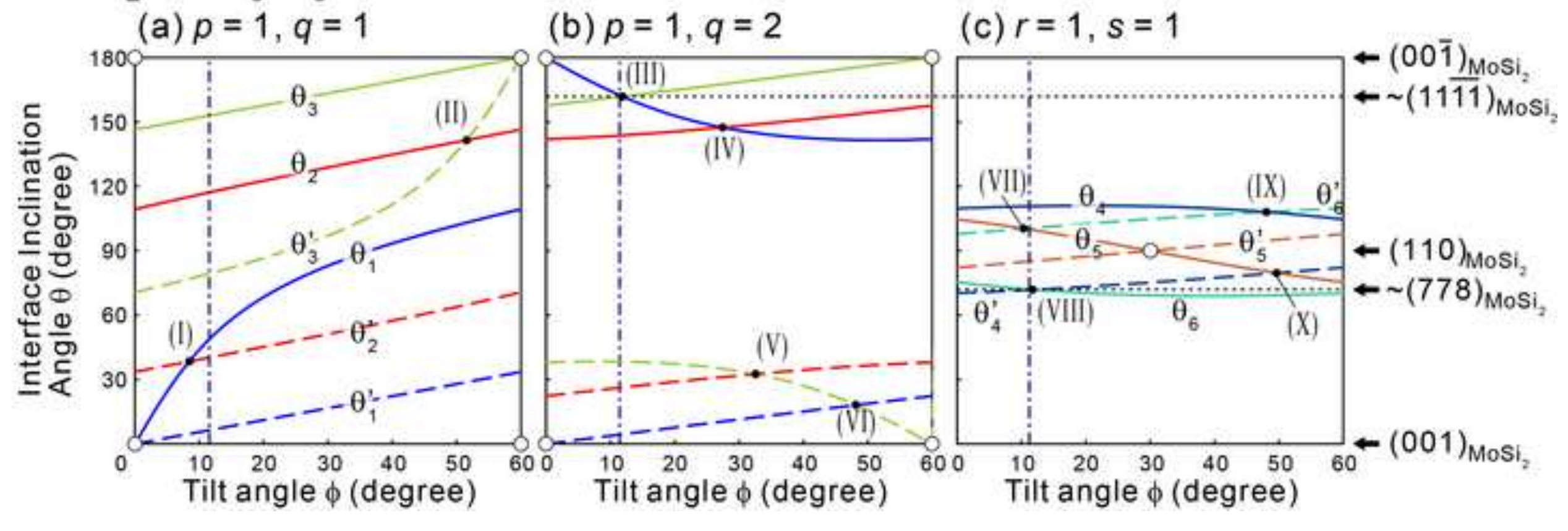


Fig. 1. EBSD orientation maps analyzed for the growth direction (GD) on (a) one cross-section and $(b, c)$ two longitudinal sections of the DS $\mathrm{MoSi}_{2} / \mathrm{Mo}_{5} \mathrm{Si}_{3} / \mathrm{Mo}_{5} \mathrm{Si}_{3} \mathrm{C}$ three-phase eutectic composite. Blue, green, and red regions correspond to $\mathrm{MoSi}_{2}$, $\mathrm{Mo}_{5} \mathrm{Si}_{3}$, and $\mathrm{Mo}_{5} \mathrm{Si}_{3} \mathrm{C}$, respectively.

Fig. 2. SEM backscattered electron image observed on a cross-section of (a) three-phase and (b) two-phase DS eutectic composites.

Fig. 3. Experimental SAED patterns taken from (a) $\mathrm{Mo}_{5} \mathrm{Si}_{3} / \mathrm{Mo}_{5} \mathrm{Si}_{3} \mathrm{C}$ and (c) $\mathrm{MoSi}_{2} / \mathrm{Mo}_{5} \mathrm{Si}_{3} \mathrm{C}$ interface regions. (b) and (d) are corresponding schematic illustrations for (a) and (c), respectively. Solid circles and open squares in the schematics indicate diffraction spots from $\mathrm{Mo}_{5} \mathrm{Si}_{3} \mathrm{C}$, and $\mathrm{Mo}_{5} \mathrm{Si}_{3}$ (b) or $\mathrm{MoSi}_{2}$ (d), respectively.

Fig. 4. Atomic-resolution HAADF-STEM images of (a) $\mathrm{Mo}_{5} \mathrm{Si}_{3} / \mathrm{Mo}_{5} \mathrm{Si}_{3} \mathrm{C}$ and (b) $\mathrm{MoSi}_{2} / \mathrm{Mo}_{5} \mathrm{Si}_{3} \mathrm{C}$ interfaces. Black arrows in (a) indicate the positions of some traces of the $(110)_{\mathrm{Mo}_{5} \mathrm{Si}_{3}}$ planes and the $(10 \overline{1} 0)_{\mathrm{Mo}_{5} \mathrm{Si}_{3} \mathrm{C}}$ planes. (c) Schematic illustration of the $\mathrm{Mo}_{5} \mathrm{Si}_{3} / \mathrm{Mo}_{5} \mathrm{Si}_{3} \mathrm{C}$ interface shown in (a). Only the atomic columns of Mo are indicated in (c).

Fig. 5. (a) Stress-strain curves of the DS three-phase (2 at.\%C) and two-phase (binary) eutectic composites tested in compression along $[1 \overline{1} 0]_{\mathrm{MoSi}_{2}}$ parallel to the growth direction. (b) Temperature dependence of yield stress of the DS composites.

Fig. 6. Deformation markings observed on (a) $(\overline{1} \overline{1} 0)_{\mathrm{MoSi}_{2}}\left(/ /(\overline{1} 10)_{\mathrm{Mo}_{5} \mathrm{Si}_{3}} / /(\overline{2} 3 \overline{1} 0)_{\mathrm{Mo}_{5} \mathrm{Si}_{3} \mathrm{C}}\right)$ and (c) (001) MoSi $_{2}\left(/ /(110)_{\mathrm{Mo}_{5} \mathrm{Si}_{3}} / /(41 \overline{5} 0)_{\mathrm{Mo}_{5} \mathrm{Si}_{3} \mathrm{C}}\right)$ of the DS three-phase composite deformed at $1000{ }^{\circ} \mathrm{C}$. (b) and (d) the schematic illustrations of the phase distribution and some typical slip traces in (a) and (c), respectively.

Fig. 7. Schematic illustrations of the misfit accommodation by tilting $\mathrm{Mo}_{5} \mathrm{Si}_{3} \mathrm{C}$ about $[0001]_{\mathrm{Mo}_{5} \mathrm{Si}_{3} \mathrm{C}}$ by the tilt angle $\varphi$ with respect to the other component phases. Dashed and dashed-and-dotted lines correspond to the misfit-accommodated interfaces.

Fig. 8. Interface inclination angle $\theta$ as a function of tilt angle $\varphi$ for the $\mathrm{Mo}_{5} \mathrm{Si}_{3} / \mathrm{Mo}_{5} \mathrm{Si}_{3} \mathrm{C}$ interfaces. Chain and dotted lines indicate the observed tilt angle $\varphi$ and inclination angles $\theta$, respectively. 
Fig. 9. Interface inclination angle $\theta$ as a function of tilt angle $\varphi$ for the $\mathrm{MoSi}_{2} / \mathrm{Mo}_{5} \mathrm{Si}_{3} \mathrm{C}$ interfaces. Chain and dotted lines indicate the observed tilt angle $\varphi$ and inclination angles $\theta$, respectively. 